\title{
Revisiting the pediment of the Palatine metroön: a Vergilian interpretation
}

\author{
by Roslynne Bell
}

\section{INTRODUCTION}

Exactly two centuries after the temple of the Magna Mater was brought to light on the southwest corner of the Palatine, excavations continue to clarify the evolution of Rome's foremost metroac sanctuary and the rituals practised therein. ${ }^{2}$ This intensive examination of archaeological material, however, only highlights the marked and surprising lack of interest in the metroön's pedimental sculpture. This may be because only a few fragments of architectural decoration remain; but our losses are ameliorated by one of the so-called Valle-Medici reliefs (a section of sculptural frieze from a Julio-Claudian monument that has never been identified securely), which depicts the front of the temple in some detail. ${ }^{3}$ Regrettably, the relief is immured high in the façade of the Villa Medici, making firsthand examination extremely difficult. None the less, a plaster cast of the original in the Museo della Civiltà Romana provides an easily accessible facsimile (FIG. 1). ${ }^{4}$ Here is the pediment as it must have

1 Much of the research for this paper, which formed part of my University of Canterbury Ph.D., was carried out during my tenure of a Rome Award at the British School at Rome. I am grateful for this opportunity and for the advice and assistance of Amanda Claridge, Lucos Cozza, Christopher Smith and Susan Walker. I would also like to thank Maria Pia Malvezzi at the School and Anna Maria Liberati at the Museo della Civiltà Romana for their help. My work has benefited greatly from the comments of a number of readers, including Alison Griffith, Tim Parkin, Lynn Roller, Tom Stevenson, Peter Wiseman and the Editor and anonymous readers of Papers of the British School at Rome. A summary of my findings was presented at a meeting of the Associazione Internazionale di Archeologia Classica in January 2007 and published thereafter in AIACNews 2007 (2): 10-11.

2 The initial recovery of the temple is thought to have been carried out by Camille De Tournon in 1809-14, but the labelling of the ruins as the temple of Ceres on Constantino Thon's plan of the Palatine (Thon, 1828: pl. 3) is testament to confusion over the identity of the structure at this time. For a list of subsequent excavations and their publications see, in particular: Pensabene, 1982: 70, 72; 1996: 206.

3 The monument, which is thought to have been similar in structure to the Ara Pacis, has been variously identified as the Ara Pietatis Augustae (Bloch, 1939; contra, Koeppel, 1982) and the Ara Gentis Iuliae (Rehak, 1987; 1990). At the time of writing, attempts are being made to reconstruct the monument in the Museo dell'Ara Pacis, where the structure is identified tentatively as the Ara Reditus Claudii (Rossini, 2006: 102).

4 Seen today, the cast is reunited with a companion panel showing the metroön's flank (Cozza, 1958). 
appeared after CE 3, when a fire necessitated Augustus's restoration of the temple and, most likely, his provision of new exterior sculpture. It has long been acknowledged that architectural decoration was a primary vehicle for the communication of Augustan ideology. ${ }^{5}$ Yet, despite belonging to one of a select group of temples singled out by name in the Res Gestae (19.2) and boasting close proximity to Augustus's own Palatine residence, the metroön's pediment is very often overlooked in discussions of the princeps's visual language. Here then, I seek to re-examine the work, and to accord it the same message-bearing potential as more celebrated Augustan pediments.

While studies of the metroön's pediment in its religio-political context are rare, descriptions of its component figures (as attested by the Valle-Medici relief) are plentiful. ${ }^{6}$ This is the logical place to begin our analysis as well. At first glance, one of the work's most striking features is its archaizing form (FIG. 2). Instead of a complex figural scene or an epic mythological narrative, we see a composition that is spare, hieratic and symmetrical. In the centre, and clearly the focal point of the scene, is the Magna Mater's ubiquitous mural crown, which sits on a mantle-draped sella with rectangular legs. Beneath the throne is a box-like object that must be a footstool.

Immediately flanking the throne are draped figures that recline with their backs to the goddess's crown and rest their outside arms on tympana (FIG. 3). Both are fragmentary, but the figure on the left appears to be male; he places his right hand on his drawn up right knee and wears a mantle wrapped around his lower body. ${ }^{7}$ The figure on the right, also commonly regarded as male, grasps a long pine branch in his left hand and seems to wear a tunic under a mantle that drapes around his lower body and left hand. Both figures are traditionally identified as galli, the eunuch priests of the Magna Mater. ${ }^{8}$

In each corner of the pediment, lions stand facing inwards; these appear to be either eating or drinking from large spherical vessels resembling dinoi. ${ }^{9}$ The relief's remaining acroterion appears atop a band of palmettes at the upper right-hand corner of the temple (FIG. 2). This is a Corybant, one of the Magna Mater's armed attendants, who stands with his left leg bent and crossed behind his right leg, and who looks downwards to the left, as if gazing at his goddess's crown. He carries a sword in his upraised right hand, which he beats against the round shield

5 See, for example: Kellum, 1982; Simon, 1986: 19-51; Zanker, 1988: 110-14 and passim.

6 See, for example: Petersen, 1902: 67-8; Tillyard, 1917: 286; Hommel, 1954: 31-2; Hanson, 1959: 15 (following an unpublished paper by Lily Ross Taylor, entitled 'The chair in the pediment of the Palatine Temple of the Magna Mater', delivered in Rome, May 1955); Vermaseren, 1977: 42-3; Koeppel, 1983: 103, cat. no. 13; Pensabene, 1985: 210, n. 13; Turcan, 1996: 43; Roller, 1999: 309-10.

7 This figure's large, bald head, as it appears on the original Valle-Medici relief, can be attributed to a sixteenth-century restoration of the work; accordingly, Cozza (1958) omitted it from his plaster cast.

8 See, for example: Petersen, 1902: 68; Tillyard, 1917: 286; Colini, 1923: 334, n. 1; Bloch, 1939: 103; Cagiano de Azevedo, 1951: 40 (archigalli); Hommel, 1954: 32; Ryberg, 1955: 69; Pensabene, 1985: 210, n. 13; Simon, 1986: 24; Turcan, 1996: 43; Roller, 2006: 53 (cf. Roller, 1999: 309-10).

9 Petersen (1902: 68), Koeppel (1983: 102) and Pensabene (1985: 210) identified the felines as panthers. However, the considerably greater frequency with which the goddess is represented with lions makes it far more likely that the latter adorned her temple. 


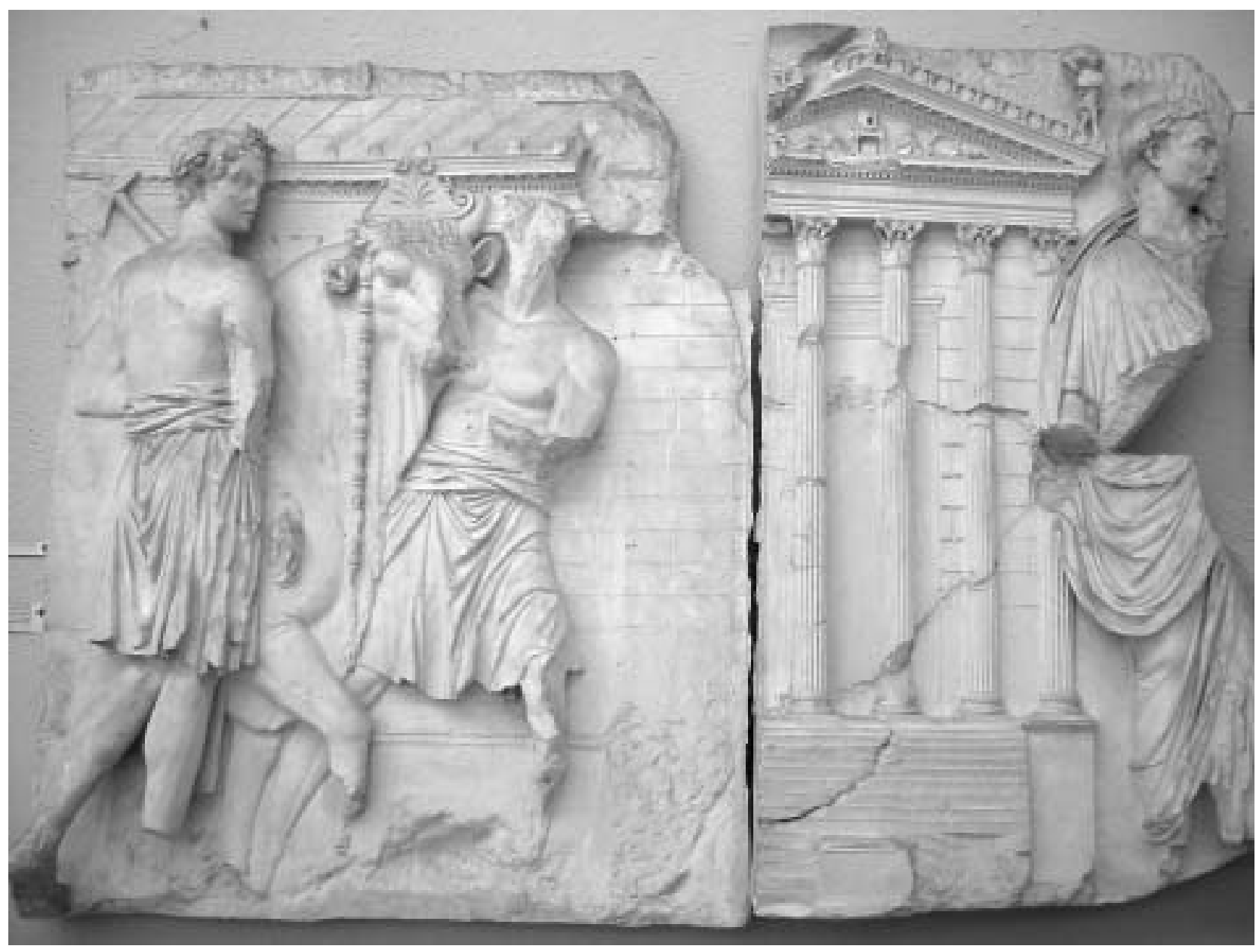

FIG. 1. The Augustan metroön. Plaster cast of the Valle-Medici metroön reliefs. Museo della Civiltà Romana, Rome. (Photo: author. Reproduced with permission, Museo della Civiltà Romana.) 


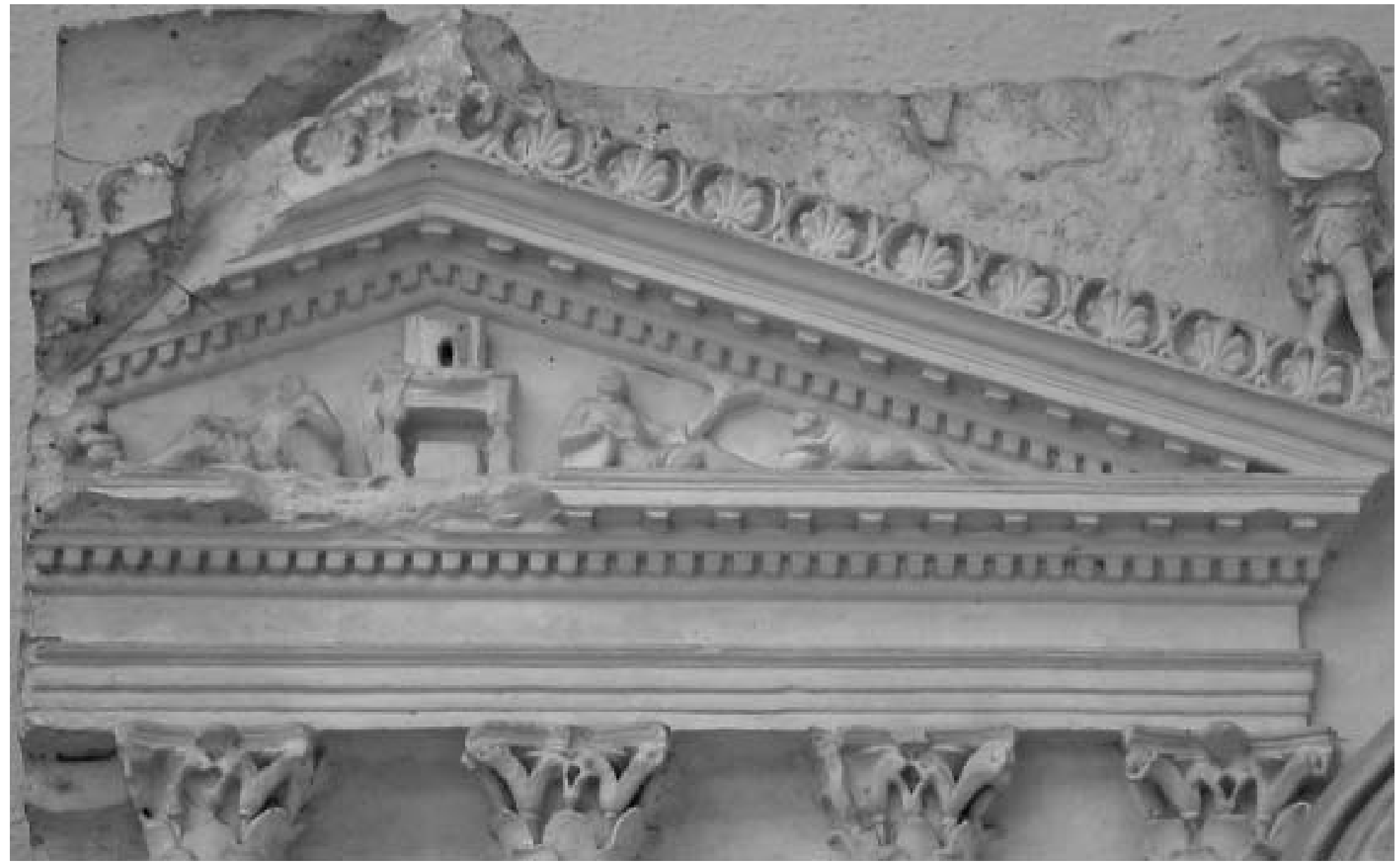

FIg. 2. Entablature of the Augustan metroön. Detail from the plaster cast of the Valle-Medici metroön reliefs. Museo della Civiltà Romana, Rome. (Photo: author. Reproduced with permission, Museo della Civiltà Romana.) 


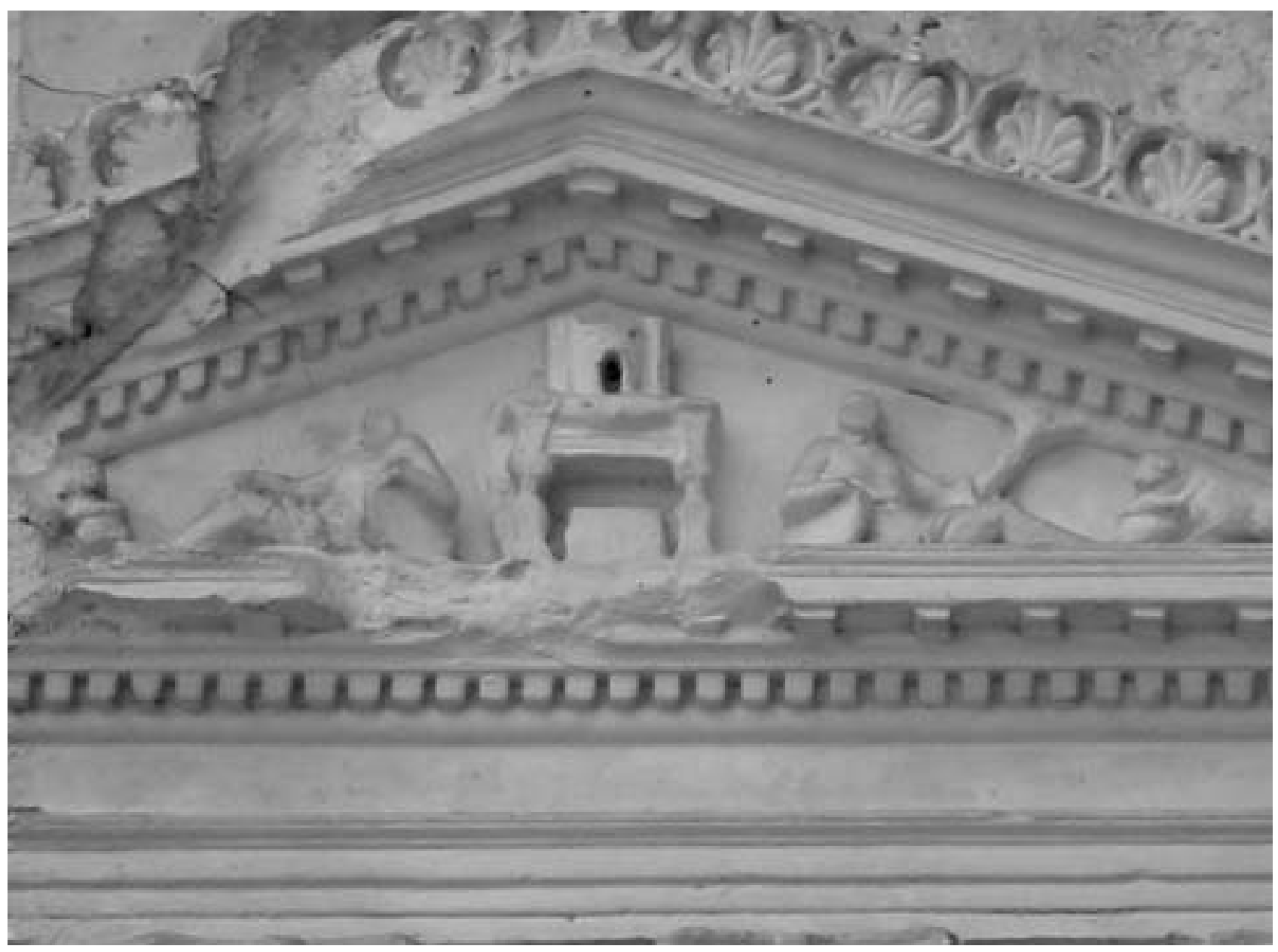

FIG. 3. Pediment of the Augustan metroön. Detail from the plaster cast of the Valle-Medici metroön reliefs. Museo della Civiltà Romana, Rome. (Photo: author. Reproduced with permission, Museo della Civiltà Romana.) 
held in front of his chest. ${ }^{10}$ The Corybant's cloak billows out behind him, and the short tunic, which he wears over trousers, swirls around his thighs. ${ }^{11}$

\section{Traditional approaches}

Clearly, close study is required of this unusual tableau, in which the subjects seem related to the cult of the Magna Mater, but the goddess herself does not appear. Within the small group of Augustan pediments whose sculpture is known to us, that of the metroön is virtually unique in terms of both iconography and composition. Nowhere else, for example, do we find either the symbols of the gods or their cult personnel emphasized in place of a deity. ${ }^{12}$ Neither do other figural arrangements so markedly reflect heraldic designs found in architectural sculpture over 600 years earlier. In part to explain these anomalies, Hommel (1954: 30-4) suggested that we see here not an Augustan composition, but one that dates from the first Palatine metroön in 191 BCE, carefully replicated by the temple's restorers in 111 BCE and CE 3 respectively. Crucially, Hommel credited Phrygian priests with the prescription of the temple's original sculptural decoration. Thus, the pediment's archaizing form and reclining figures were attributed to imitation of ancient monuments from the homeland of the galli.

A number of objections to Hommel's arguments can be raised. Not least of these is the improbability that galli, newly arrived from the East and seemingly abhorrent to Roman sensibilities, were afforded the opportunity to dictate the sculptural programme of the Magna Mater's preeminent Roman temple. Indeed, what evidence we have from the early cult in Rome attests, almost without exception, to the systematic marginalization of the goddess's foreign clergy and to the implementation of strict controls over all ostensibly non-Roman facets of the cult. ${ }^{13}$ In these circumstances, the creation of a pediment that celebrated, not the Magna Mater's newly nationalized status in Rome, but rather her eastern origins and infamous priests, seems unlikely. Furthermore, while heraldic lions are common to both Phrygian monuments and the metroön's pediment, they also appear flanking countless Hellenized images of the goddess, and need not be

10 The details of the weapon held in the right hand are vague; Vermaseren (1977-89: III, no. 2) and Pensabene (1985: 210) identified it as a lance.

11 One can assume that a similar image originally adorned the opposite corner of the pediment. Both the Phrygian cap that surmounts the pediment and the Corybant that adorns its left-hand corner in the original ValleMedici relief are sixteenth-century additions to the scene. See: Petersen, 1902: 67; cf. Turcan, 1996: 43.

12 Pediments with decoration consisting entirely of symbols, attributes and objects relating to religious cults have been found outside Rome on the Via Appia, at Tivoli and in Otricoli (Colini, 1923: 332-3, n. 2, fig. 7; Pietrangeli, 1978: 154, no. 34, fig. 167). Without exception, however, these belong to small-scale buildings where the narrow dimensions of the tympana did not permit the effective use of figural decoration. In comparison, the hexastyle metroön, with foundations measuring $33.18 \times 17.10 \mathrm{~m}$ (Richardson, 1992: 242) and a tympanum seemingly with angles of $18^{\circ}$ at the base and $144^{\circ}$ at the apex (Colini, 1923: 324) easily would have been able to sustain a complex narrative if required.

13 For example: Dionysius Halicarnassensis, Antiquitates Romanae 2.19; Valerius Maximus 7.7.6; Cassius Dio 43.48.4. 
taken as echoes of ancient tombs from the Magna Mater's Asiatic home. ${ }^{14}$ Nor should we assume that Augustus felt obliged to reproduce the temple's original decorative scheme. Although material from earlier constructional phases was incorporated into the Augustan metroön, the princeps emphatically claimed the temple as his own. ${ }^{15}$ It is difficult, therefore, to imagine that the propagandistic potential of a new, highly visible sculptural programme was ignored.

\section{The THRONE AND CROWN: ATTRibutes OF THE SELLISTERNiUm?}

To understand fully the metroön's pediment, it must be considered in a wholly Roman, and more specifically Augustan, context. For this reason, Lily Ross Taylor's identification of the scene's principal features - the throne and the crown - as representing the Roman sellisternium warrants consideration (Taylor, 1956). ${ }^{16}$ There can be no doubt that draped or cushioned chairs adorned with symbols of the gods were displayed at ceremonial banquets and ludi during the Augustan principate; fragments of the period's Acta from the secular games provide ample evidence of the practice. ${ }^{17}$ More particularly, when Varro's narrator visited the metroön to investigate cacophonous galli, he witnessed an aedile 'putting on the statue the crown he had brought from the theatre'. ${ }^{18}$ As Wiseman (1974) showed, this must surely be proof that the corona from the Magna Mater's cult statue was removed for public display during the 'theatral' days of the goddess's Megalesia. It is now widely accepted that the cult's ludi scaenici took place before the steps of the metroön itself. ${ }^{19}$ Accordingly, one can easily imagine the juxtaposition of the real sella and corona with their sculptural facsimiles, the former placed either on the temple's stylobate or on the periphery of the temporary stage below, while the latter towered above the heads of spectators on the metroön's gable. By ensuring provisions were made for the goddess's presence, organizers adhered to the decree of their ancestors that 'the Games be held on the Palatine in front of the temple in the very sight of the Magna Mater herself' ${ }^{20}$

14 Indeed, recumbent and crouched felines had long been used to fill the awkward triangular spaces of Graeco-Roman pediments. Examples include the Temple of Artemis at Corfu, numerous archaic limestone and marble pediments from the Athenian Acropolis, and the terracotta felines from the archaic temple in the Forum Boarium.

15 Augustus, Res Gestae 19.2; Ovid, Fasti 4.347-8.

16 Evidence for the draping of a throne in the Magna Mater's Hellenistic cult has been discussed by Roller (1999: 221-2). On the nature of and evidence for the sellisternium and the equivalent Greek theoxenia, see also: Taylor, 1935; Weinstock, 1957: 147-8; Hanson, 1959: 82-5.

17 CIL VI 32323 11. 38, 70, 100, 108, 137; 32329 1. 4. See further Taylor (1935: 124, n. 10; 130), who distinguished between the sellisternia attested for the secular games (deemed expiatory) and those belonging to the theatral games.

18 scaena coronam adlatam imponeret aedilis signo (Saturae Menippeae 150A (Eumenides)).

19 On this, see: Bieber, 1971: 152; Scullard, 1981: 98; Richardson, 1992: 242, 380 sub voce 'Theatrum'; Claridge, 1998: 127; Roller, 1999: 274; Dumser, 2002: 164; Nielsen, 2002: 172-5; Pensabene and D'Alessio, 2006: 38-9.

20 Cicero, De Haruspicum Responso 12.24. 


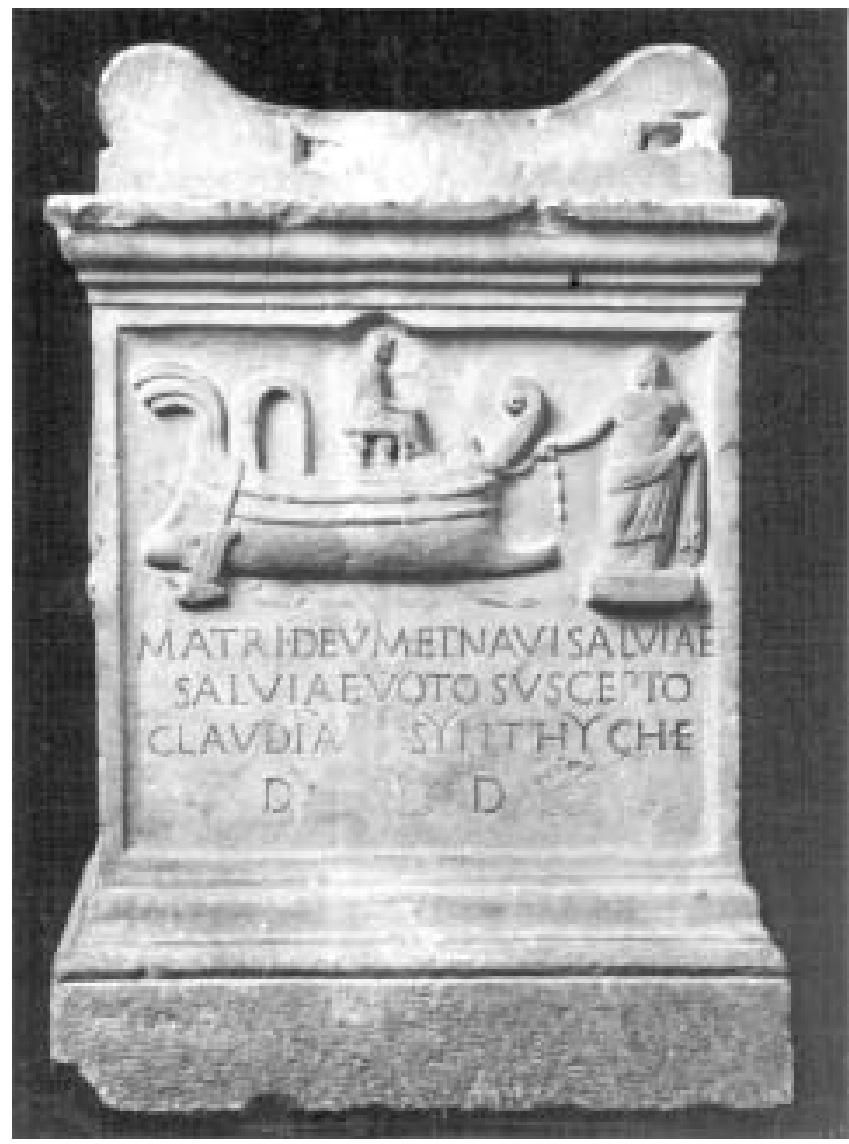

FIG. 4. Altar of Claudia

Synthyche showing the arrival of the Magna Mater in Rome. First century CE. Rome, Musei Capitolini, Centrale Montemartini. Archivio Fotografico Musei Capitolini, neg. no. MC 321/S. (Reproduced courtesy of the Sovraintendenza ai Beni Culturali, Comune di Roma.)

It seems, then, that Taylor's interpretation of the central motif on our pediment remains tenable, half a century after it was first proposed. ${ }^{21}$ Why Augustus chose to acknowledge the Magna Mater's sellisternium in such a grandiose fashion, however, has yet to be addressed. In general terms, one can appreciate the attractions of the rite for a man determined to appear the restorer of traditional religious practices and institutions. After all, unlike more ostentatious eastern facets of the cult, the sellisternium formed part of the goddess's Roman ludi, and was based on Roman customs. ${ }^{22}$ It is also likely that the throne itself had special significance, both for the cult of the Magna Mater in Rome and for Augustus. Crucially, a sella of almost identical form, with the same rectangular legs and 'carved-out incisions' (to use Richter's phrase (1966: 99)) appears on a first-century CE altar depicting the arrival of the goddess in Italy (FIG. 4). ${ }^{23}$

21 Others to accept the sellisternium theory include: Weinstock, 1957: 147-8; Hanson, 1959: 15; Wiseman, 1974: 160, 168-9; Roller, 1999: 309-10.

22 Valerius Maximus 2.1.2.

23 Vermaseren, 1977-89: III, no. 218 (and bibliography). On the throne's resemblance to Greek klinai from the fifth century BCE see: Petersen, 1902: 67. For other Greek and Roman comparanda, see: Richter, 1966: 25-8, figs 104-16 (Greek); 98-9, figs 482-3, 487-9 (Roman). Cf. Tillyard (1917: 285-6), who identified this throne, and others associated with the Magna Mater, as being 'of the Milesian type'. 
FIG. 5. Relief illustrating the Magna Mater's throne and cista carried by galli. Late second-early third centuries CE. Fitzwilliam Museum, Cambridge, inv. no. GR.51938. (Reproduced courtesy of the Fitzwilliam Museum, Cambridge.)

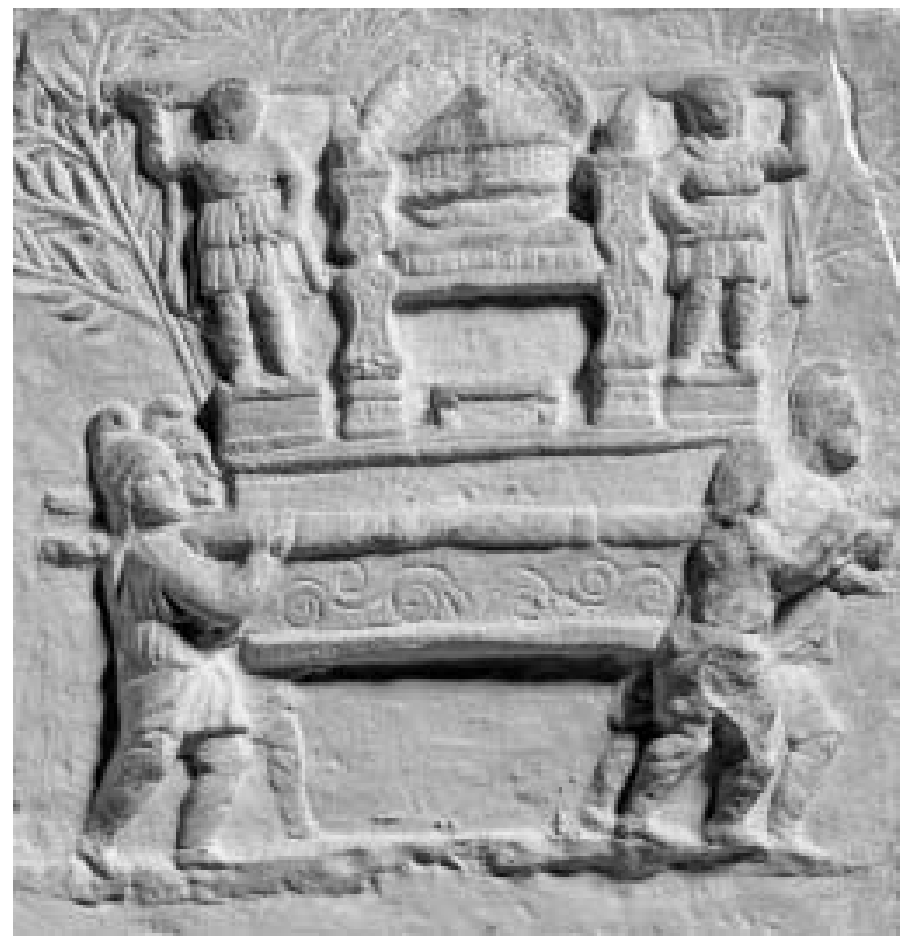

In this case, the throne bearing the cult's sacred stone (visualized in anthropomorphic form) is shown on board the Magna Mater's Phrygian ship. A similar, highly ornamental, seat adorned with the cult's cista mystica is borne in procession on the shoulders of four galli in a later relief (FIG. 5). ${ }^{24}$ The consistent appearance of this type of throne in cult art prompted Tillyard (1917: 285-6) to suggest that these works (the metroön's pediment included) all represent one throne of particular sanctity - that which accompanied the goddess's meteorite from the East in 204 BCE. This throne, it is argued, must have been housed in the Palatine metroön, where its venerability ensured not only its rescue from various temple fires, but also that it was accorded pride of place on the structure's pediment.

Expanding on this hypothesis, one can assume Augustus's cognizance both of the significance of the throne and, more importantly, of the link it provided between the imperial family and the very origins of the Magna Mater's Roman cult. It was Livia's illustrious ancestress, Claudia Quinta, who legend held had been responsible for the safe arrival of the goddess and her sacred throne. ${ }^{25}$ Thus the altar depicts Claudia Quinta holding the rope with which she freed the Magna Mater's vessel when it ran aground at Ostia (FIG. 4). ${ }^{26}$ Equally, the juxtaposition of

24 See: Vermaseren, 1977-89: VII, no. 39 (and bibliography); Tillyard, 1917; Budde and Nicholls, 1964: $77-8$, no. 125 , pl. 41.

25 Ovid, Fasti 4.291-328; cf. Livy 29.14.12-13.

26 The fact that one Claudia Synthyche dedicated the altar illustrates the continuing connections of the Claudii to the cult (CIL VI 492; $30777=$ ILS 4096). 
the Magna Mater's sella and mural crown on the metroön's pediment could have recalled honours accorded the princeps's adoptive father. In 44 BCE, the Senate voted that Julius Caesar's 'golden chair and his crown set with precious gems be carried into the theatre in the same manner as those of the gods. ${ }^{27}$ This commemorative ritual became customary after Caesar's deification in 42 BCE, and Augustus seems to have held it in high esteem throughout his life. The throne and wreath, for example, appear on coins issued early in the triumvirate (Taylor, 1935: 127), ${ }^{28}$ while Cassius Dio specifically linked a madman's shocking desecration of the revered objects in CE 13 to the princeps's death the following year. ${ }^{29}$ Compositionally, then, the metroön's throne and crown may be far removed from the complex mythological narratives and imposing figural scenes that adorned other Augustan temples, but it is clear that they lacked neither visual impact nor symbolic resonance. As a reflection of both the sellisternium and the traditional ludi held in front of the metroön, the throne and crown were entirely appropriate choices for a princeps intent on fostering Roman aspects of the Magna Mater's cult. As allusions to the Claudii's historic connections to the goddess, and to the most celebrated of the Julii, moreover, the objects were equally suited to inclusion in the pictorial vocabulary used to promote Augustus's dynastic and political ideologies.

\section{Problems With the SELListernium AND Attis}

The throne and the crown, however, were not alone on the pediment of the metroön, and we must consider the remaining figures in the light of both the sellisternium and the requirements of Augustan propaganda. For Roller (1999: 309-10), one of the few scholars to attempt this (at least with regard to the former), the pediment's meaning was simple:

The Magna Mater was to be represented at the [sellisternium] banquet by her turreted crown, while her companion Attis reclines beside her. Even her animal companions, her lions, join in the festivities by lapping up their dinner from bowls. All the elements of the traditional cult are there, the crown symbolizing the goddess as the protector of the city, the prominence of Attis and his accepted place as her companion, the tympanum, symbol of the goddess's rites, and the lions, the wild beasts who have been tamed and are, so to speak, eating out of her hand, at her table.

In its favour, Roller's interpretation accounts for the somewhat unusual depiction of the Magna Mater's paladins not as fearsome guardians, but as domesticated felines integrated into the civilized rites of the cult. Equally, one should not disregard other levels of meaning inherent

27 Cassius Dio 44.6.3 (trans. Taylor, 1935: 127); see also: Taylor, 1952: 149, n. 15.

28 For examples of this coin type, see: Sydenham, 1952: 206, no. 1332; Crawford, 1974: 513, type 497, nos. 2a-d, pl. LX, no. 20.

29 Cassius Dio 56.29.1-2. 
in the mural crown; the significance of this attribute as a symbol of the goddess's guardianship of Rome and her inhabitants was well established during the early principate. ${ }^{30}$

More problematic, however, is Roller's assessment that the figures flanking the throne are actively participating in the sellisternium banquet (FIG. 3). True, both are shown reclining in the traditional fashion of symposiasts and banqueters in Greek, Roman and Etruscan art, but here these poses can surely be attributed more to spatial constraints than to canonical banquet iconography. After all, the practice of filling awkward pedimental spaces with reclining or recumbent figures had been long-established by CE 3. Furthermore, we lack any suggestion that the draped figures to either side of the Magna Mater's throne are engaged in dining. Neither reclines on a lectus, nor are they accompanied by any of the accoutrements one would expect at a banquet; there are no tables, wine cups, bowls or food of any kind. Instead, both figures are distinguished simply by their tympana, the symbol par excellence of the cult's boisterous public rites, ${ }^{31}$ and in the case of the figure on the right, a pine branch. If either can be read as a participant at the sellisternium, then this connotation must be, at the most, incidental.

Roller's identification of the two reclining figures as a manifestation of not just one but two Attides, is less convincing and easily disproved. ${ }^{32}$ Certainly, neither figure looks like the Magna Mater's consort, who, when he appears in any great numbers in Roman art (and this is not until the second and third centuries CE), is consistently shown in oriental garb: most often a combination of tunica manicata, chlamys and anaxyrides, and almost always the Phrygian cap. ${ }^{33}$ His attributes include the syrinx and the pedum, but he very rarely holds a tympanum, ${ }^{34}$ and while the pine would eventually become closely linked with Attis, literary and archaeological sources are virtually silent on his connection to the tree during both the Republic and the Augustan principate. ${ }^{35}$ Livy, for example, did not mention the tree in his records of the goddess's

30 For example, Lucretius, De Rerum Natura 2.606-9; Ovid, Fasti 4.219-21.

31 Cf. Ovid, Fasti 4.200-15; Lucretius 2.621-2; Catullus 63.1-36. Worthy of note in the context, but considerably later in date, is the formula 'I have eaten from the tympanum, I have drunk from the cymbal', which appears in the accounts of cult ceremonies by Clemens Alexandrinus (Protrepticus 2.12) and Firmicus Maternus (De Errore Profanarum Religionum 18.1). Undoubtedly, this expression relates not to dining habits at the sellisternium, but to the Attis mysteries celebrated long after the end of the Augustan principate. For a summary of scholarly discussion on the context of this formula, see: Vermaseren, 1977: 116-19.

32 Roller herself has recently reidentified the figures as galli (2006: 53).

33 For examples from Rome and Ostia, see: Vermaseren, 1977-89: III, nos. 226, 304, 309, 336, 343-4, $357,378,383,425-6,453$.

34 Of the numerous depictions of Attis found in Rome and Latium, and listed by Vermaseren (1977-89), only two show the youth holding a tympanum. One, a taurobolic altar dated to CE 295 (Vermaseren, 1977-89: III, no. 357) can scarcely be deemed relevant to the metroön's Augustan pediment. The other, an undated marble statue (Vermaseren, 1977-89: III, no. 253) clearly represents Attis hilaris, an iconographic type commonly associated with later accounts of the youth's resurrection (Vermaseren, 1966: 39-59; 1977: 123; 1986: 33-5, nos. 240-78).

35 Cf. Arnobius, Adversus Nationes 5.5-7. Such was the evident popularity of later scenes in which Attis was associated with the pine that it is not possible to give an exhaustive list here. However, notable works from Rome and its environs include: Vermaseren, 1977-89: III, nos. 201, 236, 324, 357, 384, 447. 
arrival in Rome or the Megalesia. ${ }^{36}$ Nor does the pine feature among the emblems of the Magna Mater or the paraphernalia of her adherents, which Lucretius and Ovid were otherwise at pains to explain in their accounts of the cult. ${ }^{37}$ That Ovid knew of some connection between Attis and the tree is clear, but his claims that the youth was variously transformed into and killed by a pine suggest that Attis's association with the tree was not yet well known or understood. ${ }^{38}$

More significantly, it is unlikely that Attis enjoyed sufficient status in the Roman cult at this time to warrant incorporation on the metroön's pediment. If poor quality terracottas found in the temple's Republican strata indeed represent the youth (and this is debated), these can hardly be taken as official offerings to a deified companion of the Magna Mater. ${ }^{39}$ Certainly, none of the accounts detailing the goddess's arrival in the city mentions an accompanying consort. $^{40}$ Nor, it seems, did Attis play a role in cult ceremonies prior to the introduction of March festivals in his honour during the Claudian period. ${ }^{41}$ True, Ovid mentioned him in Fasti 4.221-46, but references here to the youth as a Phryx puer (223) make it clear that Attis was not presented as the goddess's official consort, but simply as a figure from cult legend, included to elucidate the practice of self-emasculation by galli. ${ }^{42}$

\section{Problems With GALLI}

While Roller's case for Attis has received little subsequent support, the prevailing conviction that the metroön's reclining figures were galli is such that Turcan (1996: 43) described the pediment as an 'iconographic homage to Cybele's mutilated servants'. Yet the arguments of incompatibility in terms of appearance and status levelled at Attis can be applied also to his priestly imitators. First and foremost, the reclining figures share few traits with the typical guise of a gallus in Rome. Representations of galli in art are not abundant, but the distinctive and remarkable appearance of the Magna Mater's priests made an impression on many of the city's historians and poets. Accounts may differ in their degree of disapproval or approbation of the galli, but descriptions

36 Cf. Livy 29.11.14, 36.36.

37 Cf. Ovid, Fasti 4.179-390; Lucretius 2.598-645.

38 Ovid, Metamorphoses 10.103-5; Ibis 507-8. The lack of a canonical and widespread version of this part of the Attis story also might explain why Catullus (63.2-3) neglected to mention specifically the pine tree, despite having the neophyte Attis castrate himself in the shady, forest-wreathed home of the goddess (opaca silvis redimita loca deae).

39 On this, see: Beard, North and Price, 1998: 98. The figures have been identified also as ex-votos from mothers wishing to place their sons under the Magna Mater's protection (Lancellotti, 2002: 77-9; contra, Roller, 2003) and even as personifications of penises (Butler, 1998: 247). On the terracottas, see: Romanelli, 1963: 261_ 90; 1964: 619-26 (= Vermaseren, 1977-89: III, nos. 12, 35, 37, 39, 41, 51-2, 56, 58-9, 62-3, 79, 127, 140-2, 151, 157, 180); and, for their redating: Coarelli, 1977: 10-13; 1982: 40-1.

40 Cf. Livy 29.14; Ovid, Fasti 4.247-347; Silius Italicus, Punica 17.8-58.

41 Cf. Lucretius 2.600-45; Dionysius Halicarnassensis, Antiquitates Romanae 2.19.

42 See further: Showerman, 1900: 55. Likewise, the Attis immortalized in Catullus 63 is most commonly thought to be a generic acolyte, rather than the consort of the goddess (Showerman, 1900: 55-6; Lambrechts, 1952: 149-50; Wiseman, 1985: 206; Roller, 1997: 551-2; Roller, 1999: 304-7). 


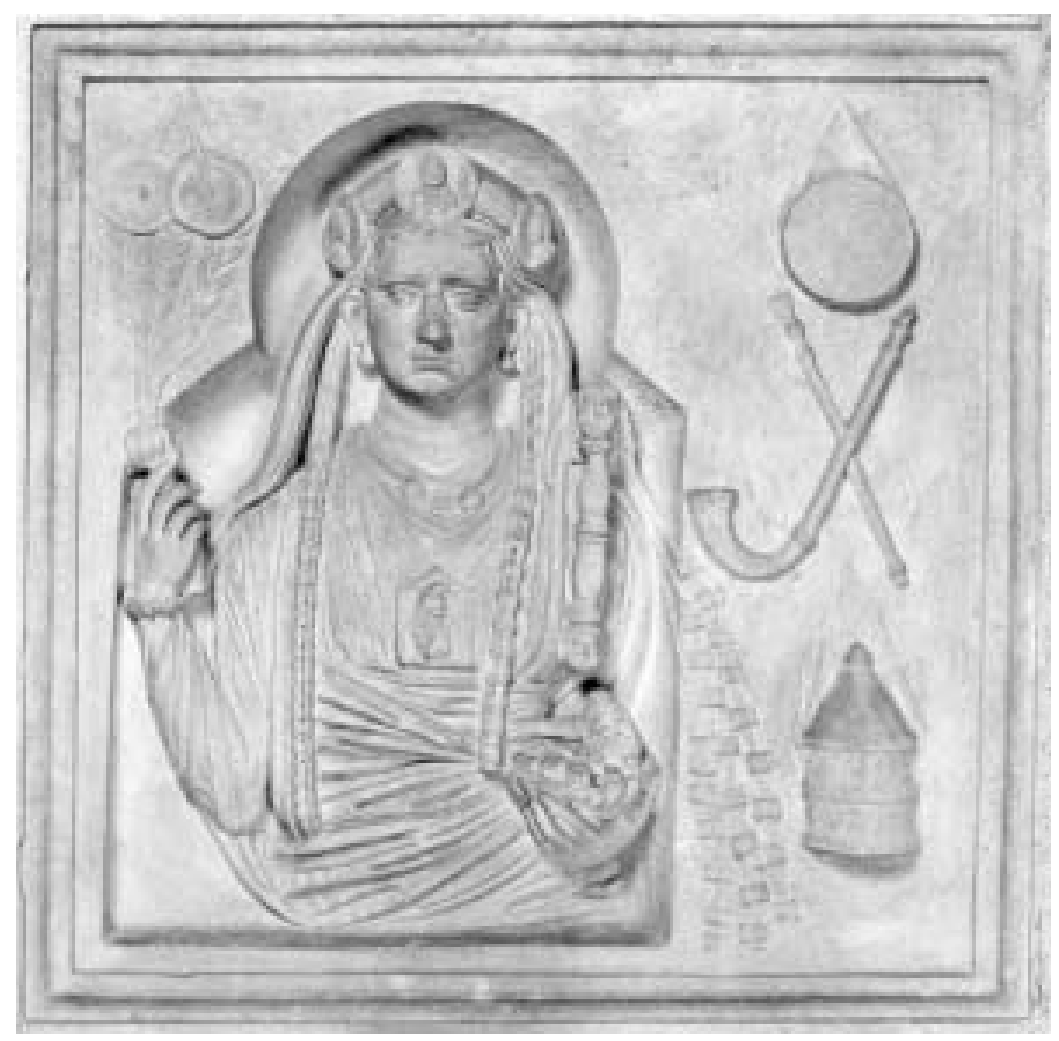

FIG. 6. Marble relief of a gallus. Mid-second century CE. Rome, Musei Capitolini, Centrale Montemartini. Archivio Fotografico Musei Capitolini, neg. no. MC 1207. (Reproduced courtesy of the Sovraintendenza ai Beni Culturali, Comune di Roma.)

of the flamboyant priests are consistent. We are given a clear picture of effeminate devotees: eunuchs with flowing perfumed hair, long colourful robes and extravagant jewellery. ${ }^{43}$

Later sculptural depictions of galli from votive offerings and funerary monuments confirm our literary accounts. A mid-second century CE relief found near Lanuvium, for example, presents a richly-adorned gallus wearing a tunica manicata, veil, infulae, an elaborate diadem, earrings, a torque and a naiskos-shaped plaque enclosing a bust of Attis (FIG. 6). ${ }^{44}$ He holds an aspergillum and a basket of fruits, and is surrounded by the attributes of his office: a tympanum, two flutes, a cista and cymbals. On a second-century CE cippus from Ostia, a gallus holding a scroll is shown wearing a Phrygian cap, short tunic, mantle and anaxyrides, and is again surrounded by the instruments of his cult (FIG. 7). ${ }^{45}$

43 For example, Diodorus Siculus 36.13.1-3; Dionysius Halicarnassensis, Antiquitates Romanae 2.19.4-5; Anthologia Palatina 7.223 (Thyillus); Varro, Saturae Mennippeae 119-21A, 130A(?) (Eumenides); Ovid, Fasti 4.361-6; Juvenal 6.511-16; Augustine, De Civitate Dei 7.26.

44 Vermaseren, 1977-89: III, no. 466.

45 Vermaseren, 1977-89: III, no. 422. 


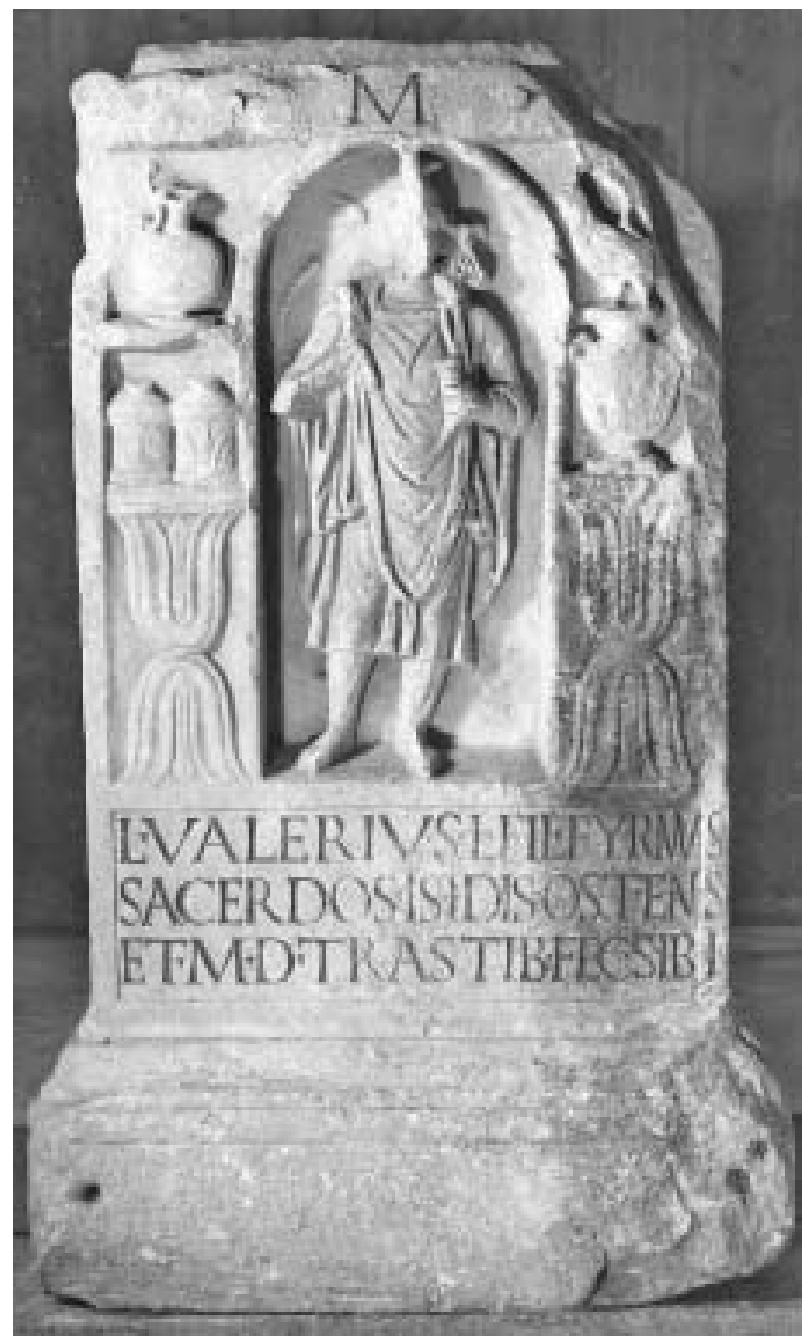

FIG. 7. Marble cippus depicting a gallus. Second century CE. Musei Vaticani, inv. no. 10762. Archivio Fotografico Musei Vaticani, neg. no. L.15.248. (Reproduced courtesy of the Direzione dei Musei Vaticani.)

These and other depictions of galli from Rome and its environs (and a few from further afield) demonstrate that not all priests of the Magna Mater wore identical clothes or possessed the same accoutrements. ${ }^{46}$ However, all find common ground in the extent to which their bodies were concealed. Whether it was a short tunic and anaxyrides or a tunica manicata with a mantle or veil, the outfits worn by galli were all-encompassing and, more significantly, clearly exotic. In comparison, the figures on the metroön's pediment conform to long-established GraecoRoman conventions of attire. They exhibit no sign of veils, tresses of hair or long decorative fillets. Nor is there any suggestion of attributes other than the tympanum and the pine branch. That the

46 Other representations include: Vermaseren, 1977-89: III, nos. 250, 307; IV, no. 94; VI, no. 530; VII, no. 39. Representations of archigalli wearing similar garments include: Vermaseren, 1977-89: III, nos. 249, 446-8. 
former was closely associated with the Magna Mater's priests is inarguable. But it seems that the latter did not assume significance in the goddess's Roman cult until the introduction of the arbor intrat rite in the mid-first century $\mathrm{CE} .{ }^{47}$ Even then, the pine seems to have had a negligible impact on cult iconography until at least the second century. Had the pediment's designer intended to represent a gallus, he clearly had an extensive repertoire of distinctive and traditional garments at his disposal. ${ }^{48}$ Any number of alternatives to the simple mantles and tunic that we see would have been more in keeping with iconographic tradition, and would have ensured that the figures were easily identifiable as the goddess's Asiatic clergy.

Appearance aside, we must also ask what, if anything, Augustus stood to gain by featuring galli so prominently in his metroac pediment. The sheer volume and complexity of evidence concerning the status of galli in Rome prevent a detailed examination of this topic here. ${ }^{49}$ However, even the most cursory survey of literature from the first centuries BCE and CE attests to the gulf that existed between Roman enthusiasm for the Magna Mater and repulsion or, at the very least, ambivalence towards her emasculated priests. Dionysius of Halicarnassus clearly articulated these paradoxical sentiments when he recorded that while the Idaean goddess was worshipped according to Roman customs (with praetors performing sacrifices and holding games in her honour), her priests and priestesses were Phrygian. The latter participated in the un-Roman activity of begging for alms, and processed through the streets dressed in colourful robes accompanied by clamorous music. A law and/or a decree of the senate prohibited the involvement of native Romans in such indecorous rites. ${ }^{50}$

Not all writers exhibited Dionysius's detachment when describing the behaviour and status of the galli in Rome. Although Ovid's apprehension about the galli was to be allayed at the behest of the Magna Mater, the poet initially felt terror at the behaviour of the priests, whom he described not simply as eunuchs but as semimares. ${ }^{51}$ More critical, and frequently also scornful, are those who focused their attentions on the private lives of galli. The priests were scathingly called 'pretty things', 'little doves' and 'half-women', 52 and their characters, appearance, love of alcohol and

47 Johannes Lydus, De Mensibus 4.59. That the Claudius to whom Lydus referred as the institutor of the festival was the Julio-Claudian emperor, and not Claudius Gothicus (CE 268-70), is easily proved, given the appearance of dendrophori in inscriptions soon after the reign of the former. See, for example, CIL X 7 (from Regium Iulium, CE 79) and CIL VI 641 (from Rome, CE 97). On these and other epigraphical sources, see: Fishwick, 1966: 201.

48 Roller (2006) has demonstrated the importance of such attire to Rome's galli, concluding that the Magna Mater's priests deliberately used dress as a means of emphasizing their marginal sexual and social status in the city.

49 For scholarship on the galli and eunuch priests in general, see: Graillot, 1912: 287-319; Vermaseren, 1977: 96-101; Thomas, 1984: 1,525-8; Beard, 1994; Turcan, 1996: 37-43; Roller, 1997; Roller, 1999: 301-4; Hales, 2002; Lancellotti, 2002: 96-105; Roller, 2006.

50 Dionysius Halicarnassensis, Antiquitates Romanae 2.19.4-5.

51 Fasti 4.183-190. See also Varro, Saturae Menippeae 132A (Eumenides), cf. Augustine, De Civitate Dei 7.26; Juvenal 6.513 .

52 Anthologia Palatina 7.222, 233; Philodemus, Epigram 26 (in Gow and Page, 1968: 366-7). On the latter, see also: Wiseman, 1982: 475-6; 1985: 204. 
deviant sexual proclivities were held up to ridicule. ${ }^{53}$ To Catullus, galli were deluded, and their fate as alienated, counterfeit women (notha mulier, 63.27) was something to be pitied, and avoided at all costs.

Nowhere do we find the disparity between the tutelary, well-received character of the Magna Mater and the contemptible nature of her foreign priests more obviously highlighted than in Vergil's Aeneid. Although the poet did not mention the galli by name, references to them, and to prevailing Roman attitudes, are unmistakable. In book four, Dido's Carthaginian suitor Iarbas refers to Aeneas as 'that Paris with his half-male retinue', and, using imagery more commonly applied to the galli, describes the Trojan as sporting a 'Phrygian cap fastened beneath his chin, and oil-steeped hair' (4.215-17). Later, the Rutulian warrior Numanus contrasts the hardy and vigorous Italians with the effeminate and idle Aeneadae, calling them Phrygian women who dress in bright yellow and purple robes, long-sleeved tunics and caps attached with ribbons (9.598-620). The connection between the foreigners and the Magna Mater's priests is further underlined as Numanus instructs the Trojans to 'go to the heights of Mt Dindymus ... [from whence] the drums and Berecynthian flute of the Idaean Mother call you' (9.617-20). Finally, in book twelve, when Turnus prays to his spear on the eve of battle with Aeneas, he asks that he be able to "lay low the body of this eunuch Phrygian, to rend and tear apart with my strong hand his breastplate, and to foul in the dust his hair crimped with hot iron and dripping with myrrh'.54

Vergil's intention was surely not to portray Aeneas, the hero of the epic and the forefather of Rome, as either a eunuch or in any way effeminate. Instead, these unflattering characterizations have been interpreted as a means by which the poet could emphasize the transition that would take place when the Trojans settled in Italy. As Roller eloquently stated:

just as the Magna Mater fulfilled her destiny by coming to Rome, so Aeneas will put away the trappings of his Phrygian (i.e., Trojan) background and become Latin. He will rid himself of the effeminacy of the Oriental in order to fulfil his destiny as the ancestor of Rome (Roller, 1999: 303). ${ }^{55}$

In this way, Vergil assured his audience of the undisputed supremacy of Roman customs and tradition, ${ }^{56}$ while acknowledging the dichotomy that existed in contemporary attitudes towards the Magna Mater and her exotic clergy. More could be said on this topic, but it is sufficient here to surmise that in the Aeneid, far from being positive or laudable, the association of effeminate Phrygians with the now-Roman Magna Mater was something to be risen above and, if possible, cast aside.

53 See, for example: Juvenal 2.111-16, 8.176; Horace, Satirae 1.2.119-22; Martial 3.81 (vividly translated by Simon Pembroke in Beard (1994: 175)).

54 Aeneid 12.97-100 (trans. Jenkyns, 1998: 411).

55 See also: Jenkyns, 1998: 410-13.

56 This sentiment is expressed most clearly during Juno's speech in Aeneid 12.823-8. See also Lucretius 6.614-17, for an alternative but not unrelated comparison between Phrygian and Roman practice. 
As literary sources and the cult's archaeological record attest, Augustan prejudices notwithstanding, the galli were destined to remain an integral and distinctive part of Roman Magna Mater worship. This does not mean that Augustus felt compelled to refer to them in the pediment of the metroön, ${ }^{57}$ for notoriety is hardly a guarantor of propagandistic worth. ${ }^{58}$ Indeed, such was the disassociation between the galli and Rome's establishment that the priests may even have been perceived as a threat to the very stability of the city. As Beard (1994: 177-8) demonstrated, their claims to direct inspiration from the goddess and the all-inclusive nature of their rites challenged traditional Roman power structures and long-standing social and cultural norms. Augustus could not have been blind to the dangers inherent in encouraging and validating a group so diametrically opposed to his own campaign for Roman mores and virtus. For this reason, the admission of at least one of his liberti into the ranks of the Magna Mater's flamboyant eunuchs has been seen as a move to increase imperial control over the cult's foreign elements. ${ }^{59}$

\section{A NEW interpretation}

\section{THE PINE BRANCH}

Having argued against the traditional labelling of our pediment's two main figures as either galli or their mythic paradigm Attis, it remains for me to suggest an alternative interpretation. The key to this endeavour lies, once again, with the pine branch - an anachronism when viewed as an Augustan symbol of cult personnel, but entirely appropriate in the context of the Aeneid, in which the Magna Mater appears as both a national goddess of Rome and, more particularly, as the divine protectress of Augustus himself. Of course, to suggest that Vergil's poem served as the model for our pediment risks opening a methodological can of worms in which debate over the primacy of text or image in the creation of Augustan cultural output requires consideration. Whether or not Augustus planned the metroac scene with 'his' epic ('tuae ... Aeneidos': Ovid, Tristia 2.533) in mind is unknowable, but, I think, feasible. As we shall see, the close correspondence in motifs indicates that, at the very least, the two works can be deemed 'kindred artifacts', ${ }^{60}$ in which analogous ideas found symbolic expression.

57 One could, perhaps, see a parallel between the galli and the salii. Despite the fame of the latter's ritual performances and the strength of their association with the cults of both Mars and Quirinus, the salii are nowhere to be found on the Augustan pediments honouring either of these deities.

58 Interesting, here, is Quintilian's comment (Institutio Oratoria 5.12.21) that eunuch priests were unfit models for Greek sculptors and painters. On this, see: Smith, 1996: 324-5; Hales, 2002: 89-90, nn. 18-20.

59 CIL VI 496; cf. Schillinger, 1979: 339, nn. 3-4; Roller, 1999: 315. It is telling that neither galli nor archigalli appear even in the official monuments of later emperors such as Claudius and Antoninus Pius, who otherwise fostered the status of the Magna Mater's priesthood. Instead, as Hales (2002: 90) has pointed out, the majority of their images resulted from commissions by the priests themselves.

60 I borrow Thomas's term (2001: 73), which he has used to describe the relationship of the Ara Pacis and Horace's Carmen Saeculare. 
It is in the Aeneid that we find the most detailed realization of the Magna Mater as alma Cybebe (bountiful Cybele). ${ }^{61}$ Here, perhaps even at the behest of the princeps, the goddess appeared as the special deity of Troy, the supporter of Aeneas and, by extension, the patron of Rome and Augustus (the latter as head of the city's familiae Troianae (family groups of Trojan descent), and the descendant and heir of Aeneas). The occasions on which the Aeneid's Magna Mater appears as protector of the Trojans and facilitator of their journey to Latium are manifold; she is vital to the success of Aeneas's mission, and the pine is the vehicle through which she directly renders aid to her Trojan devotees. The first indication we are given of the Magna Mater's role after the fall of Troy is indirect. The city is aflame, yet Anchises is determined to remain. Only the omen of a shooting star blazing a trail to the woods of Mount Ida convinces Aeneas's father to flee and to entrust his fate to the gods of his ancestors (2.693-704). Clearly, the Magna Mater figures prominently among these deities, as almost immediately she rescues Creusa from enslavement, allowing the latter's ghost to issue Aeneas with directions that ultimately will lead him to Italy, and to the site of the new Troy (2.786-9). Before the sea-going journey commences, however, Aeneas must seek refuge and make preparations. This happens on Mount Ida, Aeneas's own birthplace, ${ }^{62}$ and, more importantly, the home of the Mater Idaea, the Magna Mater. ${ }^{63}$ Now the full import of earlier reference to the mountain's forests (silva Idaea: 2.696) is revealed, for Aeneas's fleet is constructed from the trees on Mount Ida (3.5-6). In these ships the Trojans escape, and though the journey will be long and circuitous, they will eventually arrive in Latium.

Not just any timber was used for Aeneas's fleet. It is not until book nine that we learn the Trojan ships were built of pine from the sacred groves of the Magna Mater herself. Thus, when Turnus's firebrands threaten the Berecynthian mother's beloved trees (9.82), the poet recounts a plea made by the goddess to Jupiter during the vessels' construction:

... da, nate, petenti,

quod tua cara parens domito te poscit Olympo.

pinea silva mihi multos dilecta per annos,

lucus in arce fuit summa, quo sacra ferebant,

nigranti picea trabibusque obscurus acernis.

has ego Dardanio iuveni, cum classis egeret,

laeta dedi; nunc sollicitam timor anxius angit.

solve metus atque hoc precibus sine posse parentem,

ne cursu quassatae ullo neu turbine venti

vincantur: prosit nostris in montibus ortas.

61 Aeneid 10.220. On this Hellenized version of the goddess's neo-Hittite name Kubaba, see: Roller, 1999: 44-7, 67, 124-5.

62 Hesiod, Theogonia 1008-10; Homer, Iliad 2.820-1.

63 The full name of the goddess at Rome was the Mater Deum Magna Idaea. See, for example, Vergil, Aeneid 9.619-20; Livy 29.10.5, 29.14.5; Ovid, Fasti 4.182; Dionysius Halicarnassensis 2.19.3. The hope and sanctuary offered by the mountain and the goddess are made clear in Aeneid 2.801, when the new day and the escape from Troy are signalled by the morning star rising over the summit of Mount Ida. 
... Grant me, my son, what I ask -

What your dear mother asks who helped you to power in Olympus.

I had a forest of pine trees, cherished for many a year, A plantation high up on the mountain dusky with glooming spruces

And maple wood: men used to bring me offerings there.

This I did gladly give to the Dardan prince, when he needed

A fleet; but now a dreadful anxiety gnaws and troubles me.

Banish my fears: let a mother's prayer be so far efficacious

That neither hurricanes nor any other stress of voyaging

Vanquish those ships; may they find it a blessing they came from my mountain.

Aeneid 9.83-92 ${ }^{64}$

Jupiter, however, is unwilling to render the ships immortal, an act that will give Aeneas immunity from the hazards of the upcoming voyage. He promises to transform only those vessels that survive the journey to Italy into Nereids. Once the Trojans make landfall in Latium and the survival of their remaining ships is jeopardized, this pledge is honoured, as vessels made from the Magna Mater's Idaean pines plunge beneath the waves, and re-emerge as sea-goddesses (9.94-122).

Taking place in the midst of battle between the Trojans and the Rutuli, the metamorphosis of Aeneas's fleet seems a jarringly supernatural imposition in the narrative. It is also an episode that is unattested in the Aeneas legend before Vergil, and as such deserves further consideration. Certainly, the transformation of ships into nymphs serves a greater purpose than simply to render Aeneas's enemies awestruck, although, with the exception of Turnus, it accomplishes this end (9.123-8). In the wider context of the epic, the metamorphosis has been interpreted as fore-shadowing the Trojans' change from a defeated and dispossessed race into Romans (Anderson, 1989: 77); this transformation, of course, is the Aeneid's major theme. It follows, then, that the pine from which the vessels are made can be seen as a metaphor not only for Aeneas and his followers, but also for their descendants, the citizens of Augustan Rome.

More immediately, the ongoing focus on the ships allows the Magna Mater to involve herself once more in the fate of her Trojan devotees. Shortly after the transformation of the fleet, Aeneas sails down the Tiber with Evander and Pallas to rejoin his army; en route, the Nereids recognize him from afar as their king (10.224). What follows is an episode that parallels the Magna Mater's first direct intervention in aid of the Trojans. Where in book two Creusa imparted information that was vital to the success of Aeneas's mission, now the nymph Cymodocea brings Aeneas news of his besieged army, tactical instructions and a prophecy of victory (10.225-45). Once 
the nymph has finished speaking, she propels Aeneas's ship forward, 'faster than any javelin or wind-swift arrow could fly', ${ }^{65}$ the sight of which gives impetus to the rest of the fleet and prompts a heartened Aeneas to beseech the goddess as alma parens Idaea deum (kind Idaean mother of the gods) to act as his guide in battle and to bless her Phrygian devotees (10.252-5).

Two things become clear. Firstly, the pines from Mount Ida are essential elements in the undertaking and eventual success of both Aeneas's journey to Italy and his subsequent campaign against the Latins; they are a sign of the goddess's favour and of her willingness to provide a tangible means by which the Trojans can realize their destiny - the eventual foundation of Rome. Secondly, the pine is extremely important to the Magna Mater herself. The goddess is in possession of sacred pine forests that she has long cherished and that serve as a place of worship for her devotees. Indeed, so deeply does she involve herself with the welfare of the pines that, although many are felled and removed to Italy in the form of ships, she remains willing to call upon Jupiter to ensure their safety.

With the Aeneid as our exemplum, therefore, the inclusion of the pine branch on the pediment of the Augustan metroön is no surprise. In the epic, as on the temple, the pine was the emblem of the Magna Mater's affection for and patronage of both the Aeneadae and Rome itself. As a symbol of the goddess's role as the protector of cities, its meaning was analogous to that of the mural crown that dominated the metroön's gable. As an allusion to the wooded Mount Ida, the goddess's Asiatic home, the pine also served to remind viewers of the Trojan heritage shared by Aeneas, Rome and Augustus himself.

Nor should we forget that Ovid also attested to the Magna Mater's association with the pine. Clear parallels exist between Vergil's account of Aeneas's vessel and Ovid's description of the Navisalvia that carried the goddess to Rome in 204 BCE. ${ }^{66}$ Both ships begin their journey in Asia Minor and are under the Magna Mater's protection. Both receive divine assistance via an intermediary (Cymodocea and Claudia Quinta, respectively) during their passage up the Tiber. And both, we are told, are constructed from the pinewoods of Mount Ida.

\section{Mount IdA}

Seen in this light, the identity of the figure that bears the metroön's pine becomes apparent, for who better to hold the branch than Mount Ida herself? Tellingly, close study of the Valle-Medici relief reveals that, rather than possessing a masculine appearance, the figure to the right of the throne is female - her gender suggested not only by anatomy and coiffure, but also by the garment she wears: a sleeveless tunic that conforms to her breasts, is girt at the waist, and is half-covered by the mantle wrapped around her thighs. ${ }^{67}$ Depictions of the personified

65 Aeneid 10.248 (trans. Day Lewis, 1998).

66 Ovid, Fasti 4.273-6.

67 Koeppel (1983: 102, cat. no. 13), a lone voice amongst analysts of the pediment, identified both reclining figures as women. Disappointingly, he failed to back up this bold claim with suggestions as to the identity of either figure. Cf. Petersen (1902: 67), who attributed the apparent femininity of both figures to their identification as emasculated galli. 
FIG. 8. Marble sarcophagus depicting Mount Ida with Ganymede and an eagle. Circa CE 200. Musei Vaticani, inv. no. 999. Archivio Fotografico Musei Vaticani, neg. no. 93VAT468. (Reproduced courtesy of the Direzione dei Musei Vaticani.)

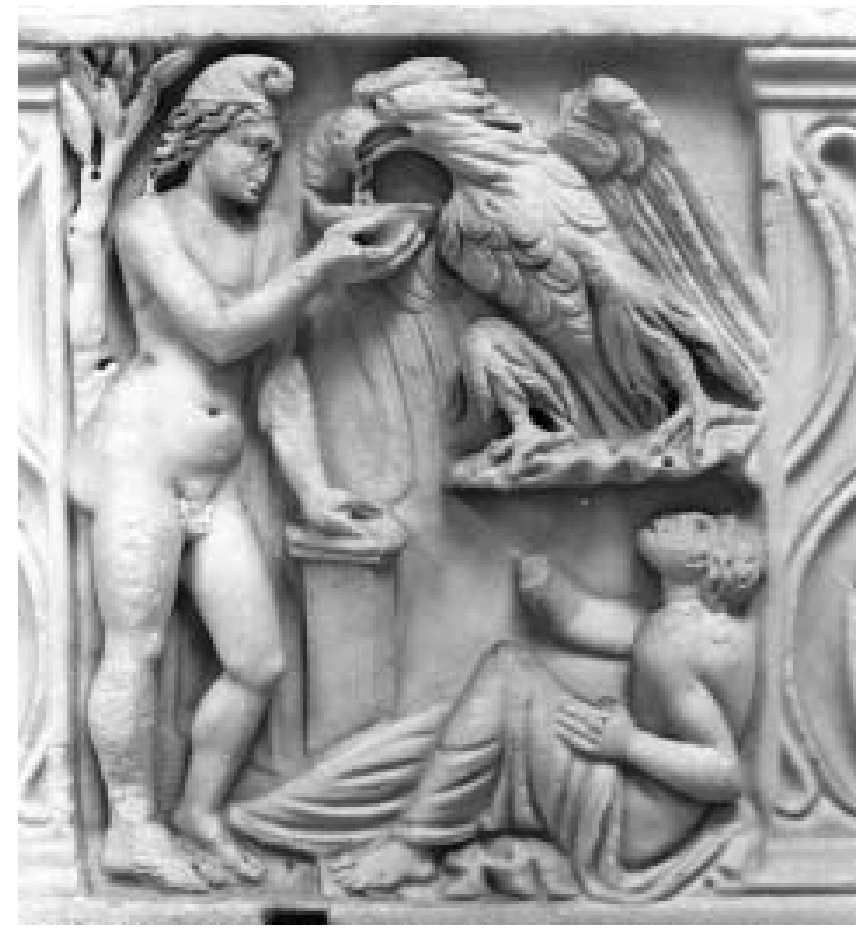
mountain are few, but a not dissimilar representation of the reclining Ida appears with Ganymede and an eagle on a later sarcophagus in the Vatican's Cortile del Belvedere (FIG. 8). ${ }^{68}$ More significantly, bronze coins from Scamandria in the Troad dated to the fourth century BCE reveal that the visual association of Ida and the pine was long-standing; here the pine-crowned Ida (or perhaps the mountain's eponymous nymph) appears on the obverse, while the pine tree itself decorates the reverse (FIGS 9 and 10). ${ }^{69}$

It is well attested by literary and archaeological sources that the Magna Mater's Roman devotees recognized Mount Ida as their goddess's eastern home. When consulted over conditions in Rome during the Second Punic War, the Sibylline books had been specific in their instruction for Romans to 'fetch the Mother of the Gods; she is to be found on Mount Ida'. ${ }^{70}$ The continued use of her epithet, Idaea, by Republican and Augustan poets, philosophers and historians, ${ }^{71}$ and

68 See: Amelung, 1908: 277-8, no. 97a, Taf. 24; Conticello, 1961: 86, fig. 108; Papageorgiadou, 1990: no. 5; Sichtermann, 1992: 166, no. 143, Tafn 115.1, 116.2.

69 See: Wroth, 1894: 79, pl. XIV, nos. 12-13; Head, 1911: 548; Conticello, 1961; Papageorgiadou, 1990: nos. 1-2). A coin from nearby Scepsis dated to the reign of Caracalla (CE 198-271) shows the nymph seated on a branch at the Judgement of Paris (see Papageorgiadou, 1990: no. 3).

70 Ovid, Fasti 4.263-4. The same tradition was recorded by Livy (29.10.4), although diplomatic and political realities in 204 BCE probably meant that the goddess's aniconic stone was procured in either Pessinus or Pergamon.

71 For example: Lucretius 2.611; Cicero, De Senectute 45; Cicero, De Legibus 2.9.22; Cicero, De Finibus 5.22.64; Livy 29.10.5, 29.14.5; Vergil, Aeneid 9.619-20, 10.252; Ovid, Fasti 4.181; Dionysius Halicarnassensis 2.19.3. 


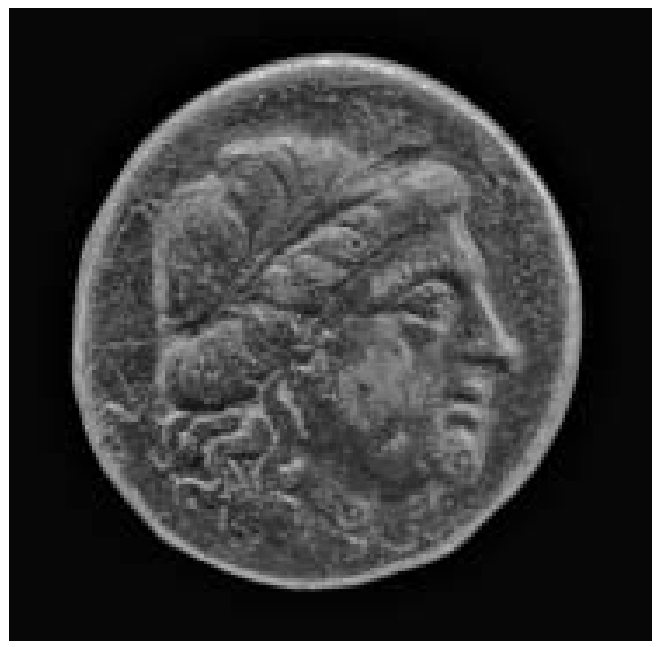

Fig. 9. Bronze coin from Scamandria depicting Ida on the obverse. Fourth century BCE. British Museum, London, inv. no. CGR69655. Photo (C) The Trustees of the British Museum. (Reproduced courtesy of The Trustees of the British Museum.)

on dedicatory inscriptions to the Mater Deum Magna Idaea, further proves the longevity and strength of the geographic association. ${ }^{72}$ On this basis alone, reference to the Phrygian peak on the metroön's pediment would be justified. The fact that it was on Mount Ida that Aeneas received the Magna Mater's aid and prepared for the journey to Latium could only have enhanced the resonance of this image. Therefore, we may interpret the temple's pine branch as a signpost to the identity of its bearer as the sylvan Mount Ida. Likewise, the tympanum on which the reclining figure leans her right arm is entirely suited to the personification. As a symbol of the cult's eastern rights, the drum reminds us that the mountain also served as a sacral area to which worshippers brought offerings for the goddess. ${ }^{73}$

We do not lack precedents for the use of topographic personifications on an Augustan pediment. Although the princeps's Temple of Quirinus (dedicated 16 BCE) has been lost, a fragment from a Domitianic monument reproduces its pedimental sculpture (FIG. 11). According to Wiseman (1995: 146-50), here is another scene that celebrates the foundation of Rome and the prospects of the Julio-Claudian dynasty. At a time when Augustus's hopes for the future of his family must have been bright, Romulus and Remus are seen on the pediment ruling together in peace. The twins appear on either side of the Quirinal's auguraculum, Romulus to the left, accompanied by Pales (the eponym of the Palatine Hill where Romulus took his first augury), and Remus on the right, next to Murcia (a topographic reference to the so-called 'lesser Aventine', the mons Murcus). A similar assemblage of deities, legendary figures and topographic personifications adorned the pediment of the Temple of Mars Ultor (FIG. 12); we will return to this work shortly. For now, it is sufficient to note that with the temples of Quirinus and Mars Ultor

72 Examples using variants of this formula in the third volume alone of Vermaseren's work (1977-89) include nos.: 8, 212, 226, 228-31, 240, 241b, 243, 258, 260-1, 296, 298, 339, 352, 357, 360, 405-7, 417, 450-1, 456-7, 464-5, 467-8.

73 Vergil, Aeneid 9.85-7. 
FIG. 10. Bronze coin from Scamandria depicting a pine tree on the reverse. Fourth century BCE. British Museum, London, inv. no. CGR69655. Photo (C) The Trustees of the British Museum. (Reproduced courtesy of The Trustees of the British Museum.)
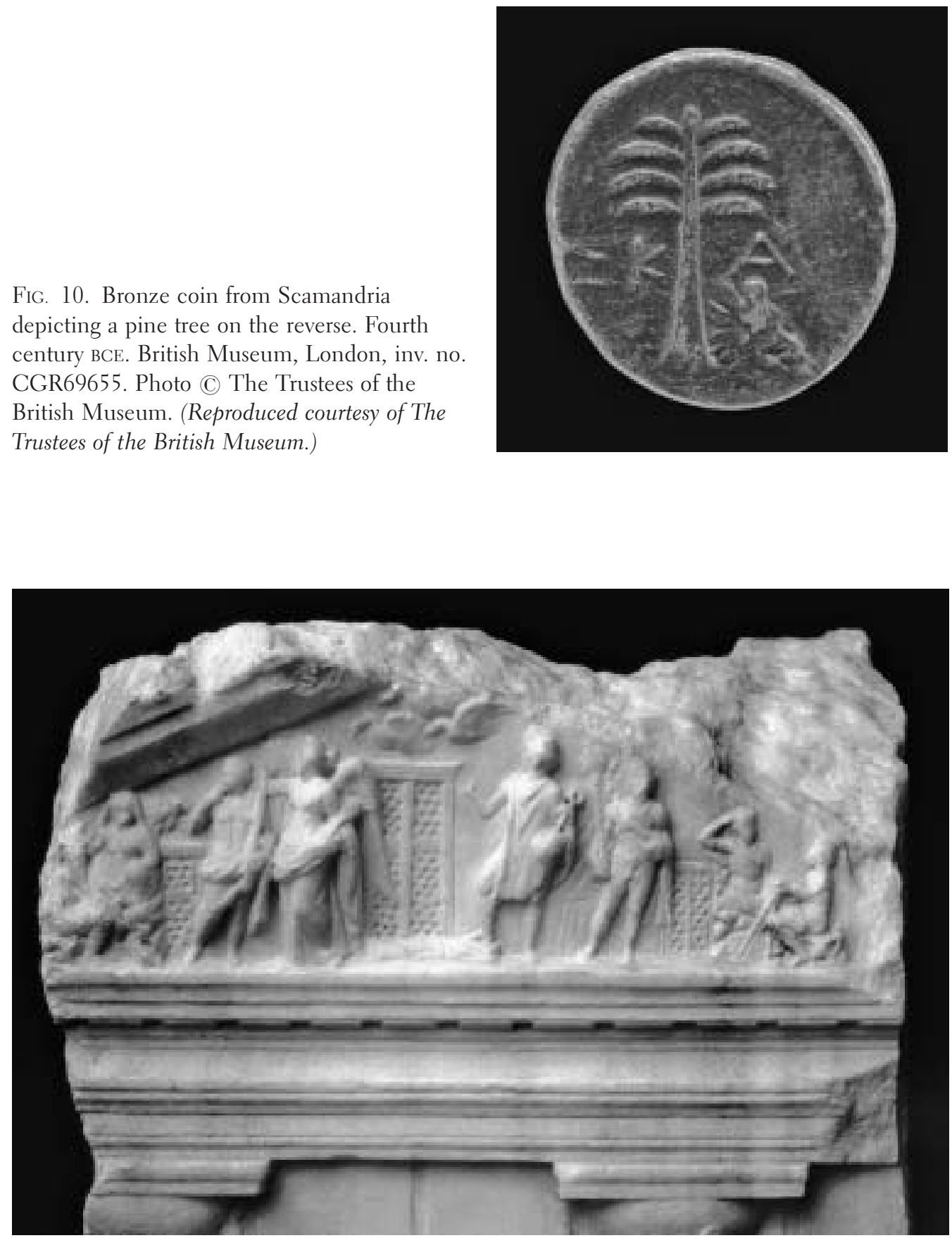

FIG. 11. Pediment of the Temple of Quirinus, showing, from left to right: Romulus, Pales, Jupiter, Mars, Victory, Mercury, Bona Dea, Hercules, Murcia, Remus. Detail from a fragmentary marble relief. First century CE. Museo Nazionale Romano, Rome, inv. no. 407121. (Photo reproduced courtesy of the Ministero per i Beni e le Attività Culturali - Soprintendenza Speciale per i Beni Archeologici di Roma.) 


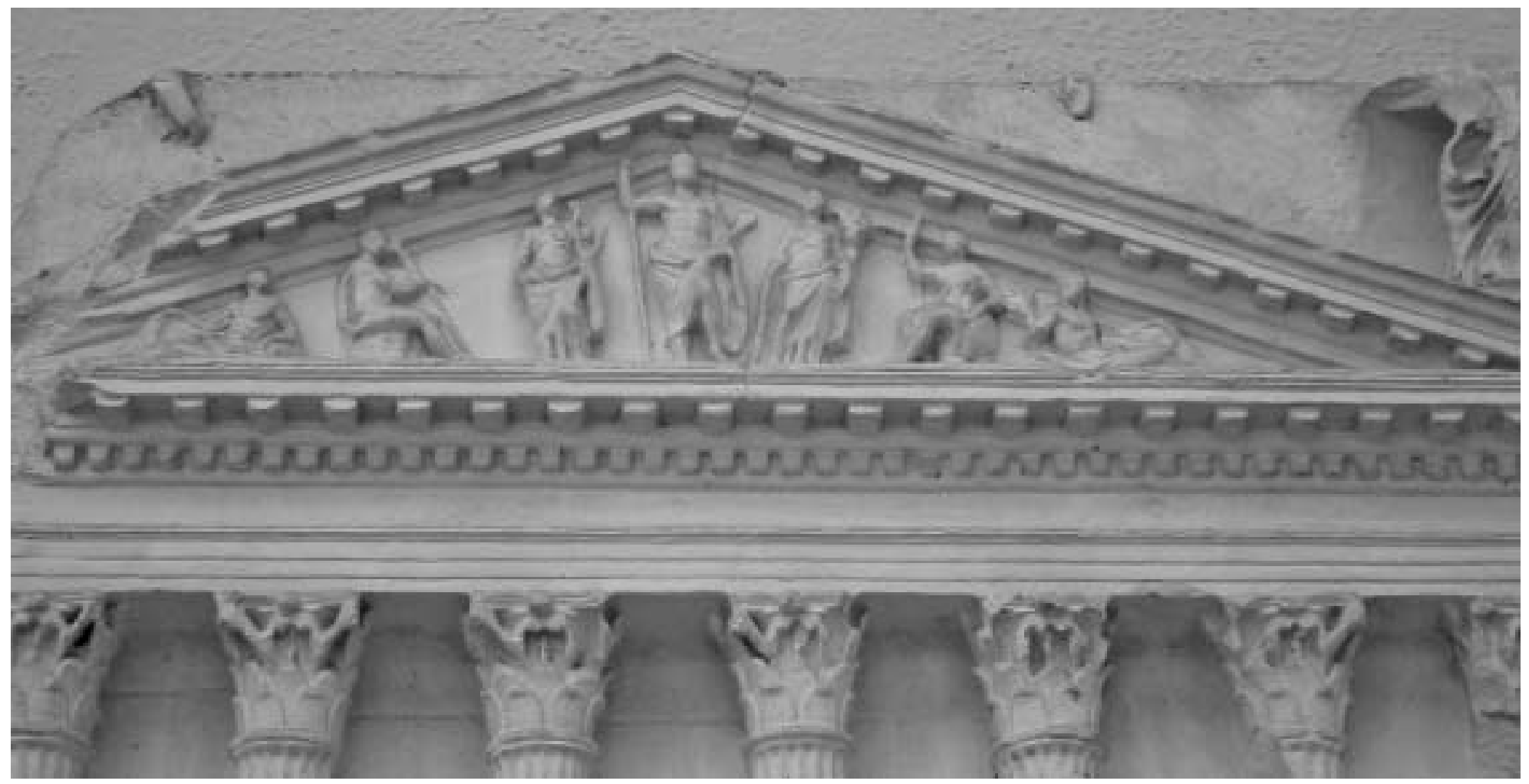

FIG. 12. Pediment of the Temple of Mars Ultor, showing, from left to right: Palatine, Romulus, Venus, Mars, Fortuna, Roma, Tiber. Detail from the plaster cast of a Valle-Medici relief. Museo della Civiltà Romana, Rome. (Photo: author. Reproduced with permission, Museo della Civiltà Romana.) 
as prototypes, Augustus may well have realized the benefits of including Mount Ida's personification on his metroac pediment. One might even speculate that he envisaged a link between all three works, for, after all, it was on the Asiatic mountain with Aeneas that Rome's story truly began. A new chapter was written when Romulus first set foot on the Palatine; now it was Augustus, the descendant of both legendary figures, who was to initiate a new Golden Age in the city's history.

It does not require an extensive search to find these ideas reflected in Augustan literature: Anchises eloquently expresses them in a long speech to his son in book six of the Aeneid (6.756-83). Likewise, Vergil's epic may provide a model for the metroön's depiction of Mount Ida. In book ten, when Aeneas sails against the Latins, he does so in a ship whose figurehead takes Mount Ida's form (10.156-8). This image was most dear to the Trojan exiles (profugis gratissima Teucris), reminding them of their far-off homeland. In fact, so striking is the connection between the mountain and the figurehead, Hardie went so far as to suggest that it is the mountain itself which is uprooted and carries the Trojan leader over the sea' (Hardie, 1987: 168). ${ }^{74}$ Representations of Roman vessels, both naval and mercantile, displaying tutela of this type clearly show anthropomorphic images of guardian deities placed prominently at bow and aft. $^{75}$ Combine this form of figurehead with Vergil's emphatic reiteration of Mount Ida's importance to both the Magna Mater and her Trojan devotees, and we have the formula, if not the catalyst, for an image of Ida personified on the metroön.

\section{LiONS AND A CORYBANT}

Aeneas does not sail against his enemies with only the apotropaic device of his goddess's sacred mountain for protection. Two lions rise from beneath the image of Mount Ida on the prow of his ship. ${ }^{76}$ These, of course, are the Magna Mater's feline escorts, which in legend and art pull the goddess's chariot, just as they must have seemed to draw Aeneas's ship across the waves. They are also the lions that appear on the metroön's pediment. Never quite satisfactorily explained by reference to the sellisternium, these animals can thus be seen as yet another reflection of Vergilian imagery, in this case recalling the juxtaposition of Mount Ida and the Magna Mater's lions on Aeneas's ship.

Significantly, identifying the Aeneid as a 'blueprint' for our pediment, and acknowledging Mount Ida's eminence both in the epic and on the temple, helps to elucidate other elements of the metroön's architectural sculpture. Paramount among these are the tympana upon which the two reclining figures lean and the Corybant acroterion. With these in mind, it is

74 Cf. Lambrechts (1951: 52, n. 3): 'On peut tout aussi bien comprendre que le navire d'Enée transporte la déesse - Idaea - qu'une representation symbolique du mont Ida' (One can just as easily understand that Aeneas's ship transports the goddess - Idaea - a symbolic representation of Mount Ida).

75 For examples, see Casson (1971: pls 125, 146), who also noted the existence of an Attic ship from the fifth century BCE named Idaia (1971: 350, n. 39); this led Harrison (1991: 104) to speculate that Aeneas's ship was named either Ida or Idaea.

76 Vergil, Aeneid 10.156-7. 
important to recall that the Augustan epic in fact features two mountains named Ida. The first and foremost of these is, of course, the Trojan home of the Magna Mater. From here, Troy's exiles embark on their journey with the blessing and support of their goddess. However, the Aeneadae travel to another Mount Ida when Apollo, via the Delian oracle, instructs Aeneas and his followers to 'seek out, then, your first mother' (3.96). This Anchises erroneously interprets not as a reference to Italy, but rather to 'a sea-girt island called Crete, Juppiter's birthplace ... [where] a Mt Ida stands ${ }^{77}$ It is from Crete, the old man recollects, that Teucer, a famous ancestor of the Trojans, migrated to the Troad, and 'the Great Mother, the patron of Cybele, the cymbals of the Corybantes, the grove of Ida . . and the lions yoked for her chariot' are derived. ${ }^{78}$ Naturally, as the Trojans are destined to settle in Latium, nothing comes of the subsequent and short-lived expedition to Crete.

The passage describing the detour to the second Mount Ida takes just under a hundred lines in book three of the Aeneid (3.94-191), but it resonates beyond its brevity. Here Vergil again confirms the primacy of the Magna Mater as an ancestral goddess of the Trojans and thus of Rome. Moreover, with the same aetiological spirit displayed by Lucretius and Ovid, the poet grasps the opportunity to legitimate a number of 'foreign' and perhaps disturbing aspects of the goddess's cult in Rome. The lions that appear in Catullus as fearsome enforcers, charged with ensuring an acolyte's obedience, are shown by Vergil simply to be loyal companions that are yoked to the goddess's chariot. ${ }^{79}$ Echoes of this benign characterization (of course influenced by the apotropaic nature of the lions' relationship to Aeneas) can be seen in the domesticated felines who seemingly participate in the sellisternium on the pediment of the metroön. Similarly, by designating the Cretan Mount Ida as the historic provenance of the Corybants and their tympana, Vergil confirms the venerability of the legendary figures and their musical attributes. Just as importantly, he prompts the reader to recall the circumstances in which both Corybant and tympanum came to prominence in Roman tradition - that is, as vital elements in the salvation of the infant Jupiter during his concealment on Mount Ida in Crete.

While in book three the connection between the goddess and the salvation of Jupiter is merely implied, in book nine the debt owed by the god to the Magna Mater and her followers is made explicit: while looking to ensure the preservation of her Idaean fleet, the goddess pointedly reminds her son of the role she played in his ascension to power in Olympus (9.83-4). Clearly, this is a reference to events following Jupiter's birth, when Saturnus's plans to commit infanticide were thwarted by the Magna Mater's followers. In order to prevent the infant god's detection by his father, the Corybants had drowned out his cries by beating their shields and armour. ${ }^{80}$ In the Aeneid, the import of these actions is sufficient to provoke a reciprocal favour from Jupiter, who, as we have seen, promises to transform the Magna Mater's ships into Nereids (9.94-103). If the king of the gods could thus acknowledge the Corybants, Augustus could surely do no less.

\footnotetext{
77 Vergil, Aeneid 3.104-5 (trans. Day Lewis, 1998).

78 Vergil, Aeneid 3.111-13 (trans. Day Lewis, 1998).

79 Catullus 63.76-89; cf. Aeneid 3.113, 10.157.

80 Lucretius 2.633-40.
} 
Accordingly, the Magna Mater's followers were chosen as acroteria for the goddess's Palatine temple; their heroic deeds immortalized in highly visible form as they surmounted the metroön's pediment, shown in the act of beating their upraised swords on their shields. The beating of the tympanum, Ovid tells us, evoked this activity during the cult's Augustan rites. ${ }^{81}$ Thus the presence of the drum within the pediment itself can be interpreted as a reference not only to rituals conducted on the Trojan Mount Ida, but also to the momentous events that took place in a cave on the mountain of the same name in Crete. ${ }^{82}$

To summarize, many factors point to the identification of the female on the metroön's pediment as the personification of Mount Ida. As the bearer of the pine from which Aeneas's fleet was made, the figure recalls the Asiatic home of the Magna Mater. Moreover, the inclusion of the tympanum suggests that the reclining female's symbolism was twofold, her image evoking not one, but both of the Idaean mountains accorded metroac connections in the Aeneid and in wider Roman tradition.

\section{The Palatine}

Unfortunately, the task of identifying and interpreting Mount Ida's counterpart on the left-hand side of the pediment is not so straightforward. If this individual once held an attribute comparable to the pine branch, it has long been lost. ${ }^{83}$ Nevertheless, a clue can perhaps be gleaned from the Temples of Mars Ultor and Quirinus, whose pediments were characterized by compositionally and symbolically balanced scenes. On the temple of Mars (FIG. 12), the central figure of the eponymous god is flanked by the standing goddesses Venus and Fortuna, then the seated Romulus and Roma, and finally, in the corners of the pediment, by the reclining personifications of the Palatine and Tiber. On the Temple of Quirinus (FIG. 11), two analogous scenes of augury flank the central entrance to the auguraculum on the Quirinal. To the left (according to Wiseman (1995: 146-50, fig. 16)), Pales, Jupiter, Mars and Victory are shown accompanying Romulus. To the right, Remus is seen with Murcia, Hercules (uncertain), Bona Dea and Mercury. Naturally, the need to depict each figure with specific attributes and garments meant that neither of these pediments was perfectly symmetrical. Both compositions, nevertheless, were carefully balanced: standing deity with standing deity, seated personification with seated personification, and so on, with all figures matching their equivalents in scale and attitude. As we have seen, balance was an equally defining characteristic of the metroön's pediment. The reclining figures to the left and right of the Magna Mater's throne are comparable in size and pose, and share the attribute of the tympanum. It follows that both were personifications of

81 Ovid, Fasti 4.207-13.

82 If correct, Coarelli's interpretation (1982: 42) of the arched hut shown behind the Magna Mater on the altar of Claudia Synthyche as the 'grotta dell'Ida' attests to the importance of the Cretan cave in both Roman visual imagery and the goddess's Roman cult.

83 The figure is much abraded, and its appearance in a new cast on display in the Museo dell'Ara Pacis differs slightly from its equivalent in the Museo della Civiltà Romana. Photos of the original Valle-Medici relief, however, suggest that the figure is male and has a bare torso. 
the Roman cult's most significant topographical landmarks. We must look, then, for somewhere to equal and complement Mount Ida - an important locus of worship with connections to the founding of Rome and, more particularly, a visual reminder of both the Magna Mater's status as a national deity of Rome and her patronage of Aeneas and his descendant Augustus.

Strikingly, with the Aeneid as our iconographic blueprint, we find that for each of these facets of Mount Ida, parallel messages are inherent in an image of the Palatine. Firstly, the hill is, of course, the home of the Magna Mater in Rome. It is the destination to which the black stone was brought from the East, and the site of the metroön, the goddess's original and most important Roman temple. These facts alone would have guaranteed the relevance of the Palatine's personification to any sculptural programme adorning the metroön. Entirely new levels of meaning are added, however, when one interprets the image in the light of Vergil's epic.

In book eight of the Aeneid, it is to the Palatine that Aeneas travels in search of allies for his forthcoming war with the Latins. There he meets Evander, the Arcadian king who lives on the future site of Rome; he is entertained and treated to a vision of the grandeur of the city to come, and in due course, when he departs, his cause is bolstered by the resources of his host, the promise of an allied Etruscan army, and an Arcadian escort that includes Pallas, Evander's own son. Quite clearly, a link is forged between the Trojan Mount Ida and the quintessentially Roman Palatine. In both locations, Aeneas receives aid that is vital to the fulfilment of his destiny. On Mount Ida, it is the Magna Mater whose direct intervention provides refuge for the Trojans and the means by which they are able to embark on their journey. Ultimately, however, Mount Ida will lie in their past; their future is on the Palatine, where Augustus will inherit and foster their legacy. Furthermore, it is the success of Aeneas's mission and the eventual founding of Rome that allow the goddess to realize her own destiny - to be brought across the sea to a new home on the Palatine, in the city founded by Aeneas's descendants. ${ }^{84}$ That the journey of the Aeneadae echoed the transfer of the Magna Mater from Mount Ida to the Palatine must have been apparent, both to Vergil's audience and to those who viewed the metroön's pediment. Surely it was equally obvious that, where once Aeneas had benefited from the goddess's patronage on Mount Ida, now Augustus enjoyed her favour on the Palatine.

Clearly, the inclusion of the Palatine's personification on the metroön, and more specifically its juxtaposition with Mount Ida, are explicable in terms of topographical relevance and the propaganda value of both sites to the princeps. Their presence also affords the composition the same iconographic and symbolic symmetry that characterized other Augustan pediments. Both locations were important centres of the Magna Mater's cult, one in the East, the other in the West; Mount Ida was the traditional home of the goddess, the Palatine her new abode. It may be that the pairing of the two personifications can even be read as a response to contemporary concerns about Roman identity. The Augustan principate had witnessed an unprecedented influx into Rome of new citizens from Italy and further afield. As Scheid (2003: 131) has noted, this sparked what was to become a long-lasting debate as to what

84 Ovid, Fasti 4.247-72. 
constituted a Roman and the nature of Rome itself. For his part, Augustus chose to emphasize the dual origins of the city. Most obviously, as we have seen, these concerns were manifested in Vergil's epic; their influence can be observed also in the fostering of ties between Lavinium, Bovillae and Rome, a move that brought the latter's Trojan and Latian heritage to the fore. ${ }^{85}$ By acknowledging Rome's debt, both to Troy (symbolized by Mount Ida) and to Latium (the Palatine) on the metroön, the princeps reaffirmed his reconciliation of the city's two ancestral legacies in a way that made them relevant, not only to the cult and to the Julian dynasty, but to all Romans.

To be sure of our Palatine hypothesis, however, one final test should be applied. Traditional interpretations of the pedimental figures as Attis or galli are found wanting once iconographic conventions are considered. Therefore, it is appropriate that the metroön's remaining figure be examined alongside Palatine comparanda. Here, regrettably, investigation is checked by the rarity of the Palatine's appearance in ancient art; indeed, only five quasi-secure examples have been identified (Small, 1994: nos. 1-5). Four of these show the Palatine in the context of the Lupa Romana, where the personification sets the scene. Significantly, two works, an Etruscan mirror from the late fourth century $\mathrm{BCE}^{86}$ and the so-called Ara Casali, an altar from the early third century CE (FIG. 13), ${ }^{87}$ depict the Palatine as a reclining youth draped in a mantle. He is shown similarly garbed, but respectively either seated or standing, on a Trajanic or early Hadrianic altar from Ostia, ${ }^{88}$ and on a marble fountain dated to the early third century CE. ${ }^{89}$ In two instances (the mirror and the Ostian altar), the figure identified as the Palatine also wears a petasos, but this is clearly not an indispensable attribute, and is one that could even have been worn by our pedimental figure itself.

The image of a reclining male, clad only in a mantle draped over his lower body, however, is far from unique to the Palatine; these features are also characteristic of gods, heroes, banqueters and, indeed, other topographic personifications. Thus, when considered in relation to scenes where the Palatine appears in the company of the she-wolf suckling Romulus and Remus, the best that may be said of the metroön's figure, perhaps, is that its appearance does not preclude it from being the Palatine. This is not entirely satisfactory, but we are already a step closer to understanding the figure than when it was identified as either Attis or a gallus. Fortunately, it is not necessary to build a case for the Palatine solely on comparanda involving the Lupa Romana. The Augustan Temple of Mars Ultor itself is widely thought to have incorporated the Palatine in the left-hand corner of its pediment (FIG. 12). Crucially, this personification

85 On the promotion of Lavinium by Augustus, see: Scheid, 2003: 128-32. For Bovillae's connections to both the Aeneadae and the Julii, see: Weinstock, 1971: 5-7.

86 Rome, Antiquarium Comunale; Small, 1994: 150, no. 1.

87 See: Le Gall, 1953: 26, pl. IX; Small, 1994: 150, no. 3 (illustrated in LIMC VII.2.417 as Ares/Mars no. 411); cf. Moreno, 1963: 849.

88 Rome, Museo Nazionale, inv. no. 324; Le Gall, 1953: 25-6, pl. VIII; Small, 1994: 150, no. 2; La Regina, 1998: 59-60.

89 Stockholm, National Museum, inv. no. Sk 178; Small, 1994: 151, no. 5 and fig. 


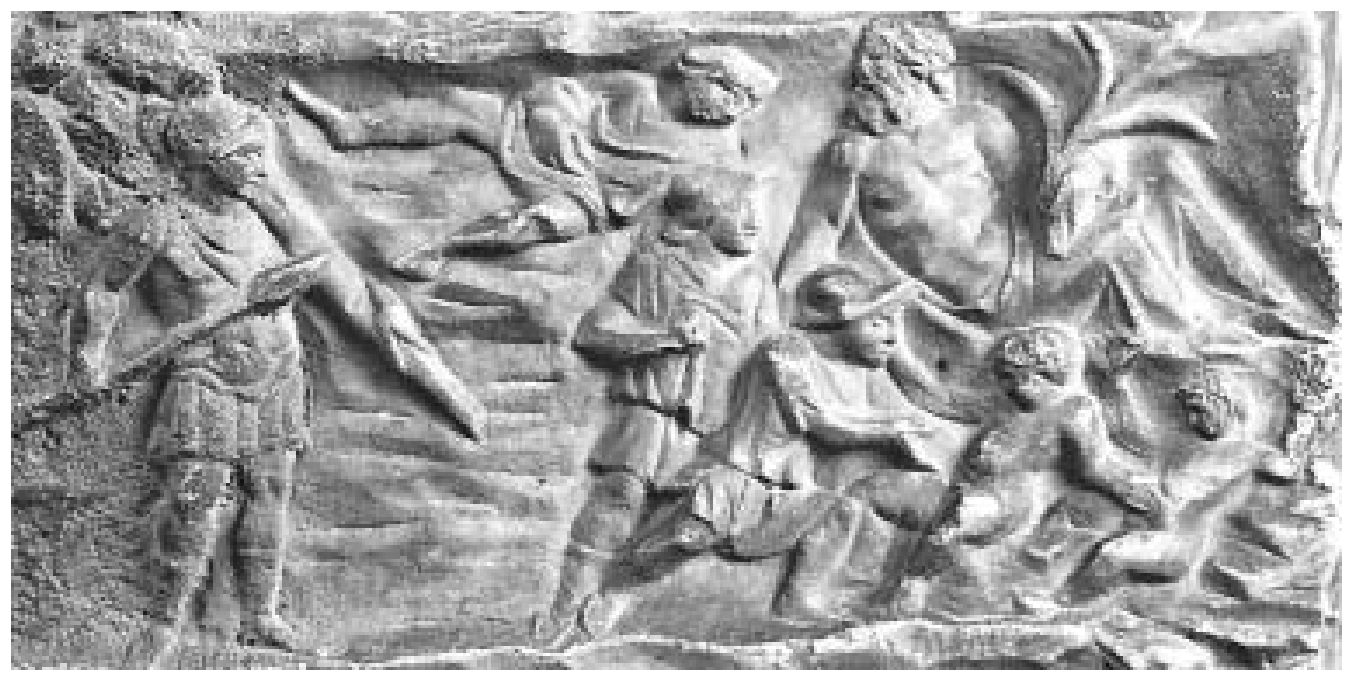

FIG. 13. Detail from the Ara Casali showing the personification of the Palatine (reclining, top left of centre) at the exposure of Romulus and Remus. Early third century CE. Musei Vaticani, inv. no. 1186. Archivio Fotografico Musei Vaticani, neg. no. 93VAT932. (Reproduced courtesy of the Direzione dei Musei Vaticani.)

exhibits many similarities to our metroac figure. ${ }^{90}$ A male with bare torso, the Mars Ultor Palatine is shown reclining; his body is wrapped from the waist down in a mantle, his right hand rests on his drawn-up right knee, and his outstretched left leg is bent slightly and inclines outwards towards the viewer. He differs from his counterpart on the metroön only in the survival of his head (turned to the right, as if observing the figures in the centre of the composition), his more muscular (or perhaps just better-preserved) upper body, and the fact that his left arm, on which he props up his body, seems to be draped over a rock, rather than a tympanum.

Such iconographic correspondence is significant. One could speculate that the earlier Mars Ultor image acted as a model when the Palatine was placed on the metroön. The two monuments may have been separated by as little as five years; perhaps they were even designed and executed by the same craftsmen. ${ }^{91}$ As we have seen, the two pediments are notable for their commonalities. Both were characterized by archaizing compositions, with component figures that were static and symmetrically disposed. Both depended on the symbolic, rather than the narrative, content of their scenes to convey Augustan ideology, and in both the overriding themes were unmistakably the history of Rome and the glorification of the princeps and the Julii.

90 For the identification of the Mars Ultor Palatine see, for example: Richardson, 1992: 162; Favro, 1996: 150, fig. 65; Galinsky, 1996: 209, fig. 111.

91 Although the princeps vowed the Temple of Mars Ultor on the eve of the Battle of Philippi in 42 BCE, the dedication ceremony did not take place until 12 May, 2 BCE. Even then, Suetonius (Divus Augustus 29.1) tells us the temple remained unfinished; he gave no further details, but one can imagine that work on the architectural sculpture, not the structure of the temple, was incomplete at the time of the inauguration. 


\section{Conclusion}

Further avenues of enquiry arise from these conclusions, not least the nature of previously unsuspected links between the Temples of Mars Ultor and the Magna Mater, and their ramifications for our understanding of the Valle-Medici reliefs. ${ }^{92}$ More broadly, the goddess's significance in the Augustan precinct on the Palatine, as manifested in works such as the Gemma Augustea and Sorrento base, also warrants reconsideration. ${ }^{93}$ For now, however, it is sufficient to reflect that effort spent reassessing the content and meaning of the metroön's pediment is amply repaid by the results. No longer, I think, can we entertain suggestions that Augustus neither cared about, nor remained detached from, choosing a subject to adorn the temple that was otherwise so closely associated with his own house and family. Nor can we sustain traditional preconceptions that figures shown in the company of the Magna Mater (represented on the pediment by her mural crown) must be either Attis or galli. To do this requires one to disregard iconographic tradition as well as to invite disquiet over the princeps's unlikely and anachronistic validation of two of the cult's most infamous eastern imports. By interpreting the metroön's reclining figures with recourse to Vergilian imagery, however, we can begin to understand and appreciate the ways in which these multivalent images formed an intrinsic part of Augustan ideology's pictorial vocabulary. As symbols of the East and the West, and of Troy and Rome, few images could have encapsulated and validated the Magna Mater's dual heritage more effectively than the personifications of Mount Ida and the Palatine. The fact that the princeps, his family, and indeed Rome itself, laid claim to this same aetiology only increased the relevance and resonance of these figures. Because of her origins on Mount Ida, the Magna Mater had been accepted into the heart of Augustan religion; equally, her temple on the Palatine was now celebrated as one of the monuments at the heart of Augustan Rome.

\section{REFERENCES}

Amelung, W. (1908) Die Sculpturen des Vaticanischen Museums II. Berlin, Reimer.

Anderson, W.S. (1989) The Art of the Aeneid. Bristol, Bristol Classical Press.

Beard, M. (1994) The Roman and the foreign: the cult of the 'Great Mother' in Imperial Rome. In N. Thomas and C. Humphrey (eds), Shamanism, History and the State: 164-90. Ann Arbor, University of Michigan Press.

Beard, M., North, J. and Price, S. (1998) Religions of Rome I. A History. Cambridge, Cambridge University Press.

Bell, R.S. (2007) Power and Piety: Augustan Imagery and the Cult of the Magna Mater. University of Canterbury, Ph.D. thesis.

92 For recent work on the so-called metatopography of the two structures and its reflection in the ValleMedici reliefs, see: Grunow, 2002: 164-7.

93 See: Bell, 2007: 107-241. 
Bieber, M. (1971) The History of the Greek and Roman Theatre (revised edition). Princeton, Princeton University Press.

Bloch, R. (1939) L’Ara Pietatis Augustae. Mélanges de l'École Française de Rome. Antiquité 56: 81-120.

Budde, L. and Nicholls, R. (1964) A Catalogue of the Greek and Roman Sculpture in the Fitzwilliam Museum Cambridge. Cambridge, Cambridge University Press.

Butler, S. (1998) Notes on a membrum disiectum. In S.R. Joshel and S. Murnaghan (eds), Women and Slaves in Greco-Roman Culture: Differential Equations: 236-55. New York, Routledge.

Cagiano de Azevedo, M. (1951) Le antichità di Villa Medici. Rome, Libreria dello Stato.

Casson, L. (1971) Ships and Seamanship in the Ancient World. Princeton, Princeton University Press.

Claridge, A. (1998) Rome: an Oxford Archaeological Guide. Oxford, Oxford University Press.

Coarelli, F. (1977) Public building in Rome between the Second Punic War and Sulla. Papers of the British School at Rome 45: 1-23.

Coarelli, F. (1982) I monumenti dei culti orientali in Roma. In U. Bianchi and M.J. Vermaseren (eds), La soteriologia dei culti orientali nell'Impero Romano: 33-67. Leiden, Brill.

Colini, A.M. (1923) Indagini sui frontoni dei templi di Roma. Bullettino della Commissione Archeologica Comunale di Roma 51: 299-347.

Conticello, B. (1961) Ida. In Enciclopedia dell'arte antica, classica e orientale IV: 85-6. Rome, Istituto della Enciclopedia Italiana.

Cozza, L. (1958) Ricomposizione di alcuni rilievi di Villa Medici. Bollettino d'Arte 43: 107-11.

Crawford, M.H. (1974) Roman Republican Coinage I-II. Cambridge, Cambridge University Press.

Day Lewis, C. (1998) (translator) Virgil, The Aeneid. Oxford, Oxford University Press.

Dumser, E.A. (2002) Magna Mater, Aedes. In L. Haselberger, D.G. Romano and E.A. Dumser (eds), Mapping Augustan Rome (Journal of Roman Archaeology Supplementary Series 50): 163-4. Portsmouth (RI), Journal of Roman Archaeology.

Favro, D. (1996) The Urban Image of Augustan Rome. Cambridge, Cambridge University Press.

Fishwick, D. (1966) The Cannophori and the March festival of the Magna Mater. Transactions of the American Philological Association 97: 193-202.

Galinsky, G.K. (1996) Augustan Culture - an Interpretive Introduction. Princeton, Princeton University Press.

Gow, A.S.F. and Page, D.L. (1968) (eds) The Greek Anthology: the Garland of Philip and Some Contemporary Epigrams II. Cambridge, Cambridge University Press.

Graillot, H. (1912) Le culte de Cybèle, mère des dieux, à Rome et dans l'empire romaine. Paris, Fontemoing et cie.

Grunow, M.D. (2002) Architectural Images in Roman State Reliefs, Coins, and Medallions: Imperial Ritual, Ideology, and the Topography of Rome. University of Michigan, Ph.D. thesis.

Hales, S. (2002) Looking for eunuchs: the galli and Attis in Roman art. In S. Tougher (ed.), Eunuchs in Antiquity and Beyond: 87-102. London, Duckworth.

Hanson, J.A. (1959) Roman Theater-Temples. Princeton, Princeton University Press.

Hardie, P. (1987) Ships and ship-names in the Aeneid. In M. Whitby, P. Hardie and M. Whitby (eds), Homo Viator: Classical Essays for John Bramble: 163-71. Bristol, Bristol Classical Press.

Harrison, S.J. (1991) Virgil Aeneid 10. Oxford, Clarendon Press. 
Head, B.V. (1911) Historia Numorum. Oxford, Clarendon Press.

Hommel, P. (1954) Studien zu den Römischen Figurengiebeln der Kaiserzeit. Berlin, Mann.

Jenkyns, R. (1998) Virgil's Experience - Nature and History: Times, Names, and Places. Oxford, Clarendon Press.

Kellum, B.A. (1982) Sculptural Programs and Propaganda in Augustan Rome: the Temple of Apollo on the Palatine and the Forum of Augustus. Harvard University, Ph.D. thesis.

Koeppel, G.M. (1982) Die Ara Pietatis Augustae: ein Geisterbau. Mitteilungen des Deutschen Archäologischen Instituts, Römische Abteilung 89: 453-5.

Koeppel, G.M. (1983) Die historischen Reliefs der Römischen Kaiserzeit I. Stadtrömische Denkmäler unbekannter Bauzugehörigkeit aus Augusteischer und Julisch-Claudischer Zeit. Bonner Jahrbücher 183: 61-144.

La Regina, A. (1998) Palazzo Massimo alle Terme. Milan, Electa.

Lambrechts, P. (1951) Cybèle, divinité étrangère ou nationale? Bulletin de la Société Royale Belge d'Anthropologie et de Préhistoire 62: 44-60.

Lambrechts, P. (1952) Les fêtes 'phrygiennes' de Cybele et d'Attis. Bulletin de l'Institut Historique Belge de Rome 27: 141-70.

Lancellotti, M.G. (2002) Attis: Between Myth and History: King, Priest and God (Religions in the GraecoRoman World 149). Leiden/Boston/Cologne, Brill.

Le Gall, J. (1953) Recherches sur le culte du Tibre. Paris, Presses Universitaires de France.

Moreno, P. (1963) Palatinus. In Enciclopedia dell'arte antica, classica e orientale V: 849-50. Rome, Istituto della Enciclopedia Italiana.

Nielsen, I. (2002) Cultic Theatres and Ritual Drama: a Study in Regional Development and Religious Interchange between East and West in Antiquity. Aarhus, Aarhus University Press.

Papageorgiadou, C. (1990) Ide II. In Lexicon Iconographicum Mythologiae Classicae V.1: 643. Zurich/ Munich, Artemis.

Pensabene, P. (1982) Nuovi indagini nell'area del tempio di Cibele sul Palatino. In U. Bianchi and M.J. Vermaseren (eds), La soteriologia dei culti orientali nell'Impero Romano: 68-98. Leiden, Brill.

Pensabene, P. (1985) Area sud-occidentale del Palatino. In A.M. Bietti Sestieri, A. Capodiferro, G. Morganti, C. Pavolini, M. Piranomonte and P. Scoppola (eds), Roma: archeologia nel centro (Lavori e studi di archeologia 6), 2 vols: I, 179-212. Rome, De Luca.

Pensabene, P. (1996) Magna Mater, Aedes. In E.M. Steinby (ed.), Lexicon Topographicum Urbis Romae III (H-O): 206-8. Rome, Quasar.

Pensabene, P. and D’Alessio, A. (2006) L'immaginario urbano: spazio sacro sul Palatino tardorepubblicano. In L. Haselberger and J. Humphrey (eds), Imaging Ancient Rome: Documentation Visualization - Imagination. Proceedings of the Third Williams Symposium on Classical Architecture Held at the American Academy in Rome, the British School at Rome, and the Deutsches Archäologisches Institut, Rome, on May 20-23 2004 (Journal of Roman Archaeology Supplementary Series 61): 31-49. Portsmouth (RI), Journal of Roman Archaeology.

Petersen, E. (1902) Ara Pacis Augustae. Vienna, A. Hölder.

Pietrangeli, C. (1978) Otricoli: un lembo dell'Umbria alle porte di Roma. Narni, Cassa di Risparmio di Narni. 
Rehak, P. (1987) A reconstruction of the 'Ara Pietatis Augustae'/Ara Gentis Iuliae. American Journal of Archaeology 91: 304.

Rehak, P. (1990) The Ionic temple relief in the Capitoline: the Temple of Victory on the Palatine? Journal of Roman Archaeology 3: 172-86.

Richardson, L., Jr (1992) A New Topographical Dictionary of Ancient Rome. Baltimore, Johns Hopkins University Press.

Richter, G.M.A. (1966) The Fumiture of the Greeks, Etruscans and Romans. London, Phaidon Press.

Roller, L.E. (1997) The ideology of the eunuch priest. Gender and History 9 (3): 524-59.

Roller, L.E. (1999) In Search of God the Mother: the Cult of Anatolian Cybele. Berkeley/ Los Angeles/ London, University of California Press.

Roller, L.E. (2003) Review of Attis between Myth and History: King, Priest and God, by Maria Grazia Lancellotti. Bryn Mawr Classical Review 2003.08.05.

Roller, L.E. (2006) The priests of the mother - gender and place. In C. Mattusch, A.A. Donohue and A. Brauer (eds), Proceedings of the XVI International Congress of Classical Archaeology, Boston, August 23-26, 2003: Common Ground: Archaeology, Art, Science and Humanities: 52-5. Oxford, Oxbow.

Romanelli, P. (1963) Lo scavo al tempio della Magna Mater sul Palatino. Monumenti Antichi 46: 201-330.

Romanelli, P. (1964) Magna Mater e Attis sul Palatino. In M. Renard and R. Schilling (eds), Hommages à Jean Bayet (Collection Latomus 70): 619-26. Brussels, Latomus.

Rossini, O. (2006) Ara Pacis. Milan, Electa.

Ryberg, I.S. (1955) Rites of the State Religion in Roman Art (Memoirs of the American Academy in Rome 22). Rome, American Academy in Rome.

Scheid, J. (2003) Cults, myths, and politics at the beginning of the Empire. In C. Ando (ed.), Roman Religion: 117-38. Edinburgh, Edinburgh University Press.

Schillinger, K. (1979) Untersuchungen zur Entwicklung des Magna Mater-Kultes im Westen des Römischen Kaiserreiches. Universität Konstanz, Ph.D. thesis.

Scullard, H.H. (1981) Festivals and Ceremonies of the Roman Republic. Ithaca (NY), Cornell University Press.

Showerman, G. (1900) Was Attis at Rome under the Republic? Transactions of the American Philological Association 31: 46-59.

Sichtermann, H. (1992) Die Mythologischen Sarkophage II. Berlin, Mann.

Simon, E. (1986) Augustus: Kunst und Leben in Rom um die Zeitenwende. Munich, Hirmer.

Small, J.P. (1994) Palatinus. In Lexicon Iconographicum Mythologiae Classicae VII.1: 150-1. Zurich/ Munich, Artemis.

Smith, J.O. (1996) The high priests of the Temple of Artemis at Ephesus. In E.N. Lane (ed.), Cybele, Attis and Related Cults: 323-35. Leiden, Brill.

Sydenham, E.A. (1952) The Coinage of the Roman Republic. London, Spink.

Taylor, L.R. (1935) The sellisternium and the theatrical pompa. Classical Philology 30: 122-30.

Taylor, L.R. (1952) Lucretius on the Roman theatre. In M.E. White (ed.), Studies in Honour of Gilbert Norwood: 147-55. Toronto, University of Toronto Press.

Taylor, L.R. (1956) Sellisternium and theoxenia. In Atti dell'VIII congresso internazionale di storia delle religioni (Roma 17-23 aprile 1955): 349-50. Florence, Sansoni. 
Thomas, G. (1984) Magna Mater and Attis. In Aufsteig und Niedergang der Römischen Welt 2.17.3: 1,500-35. Berlin/New York, De Gruyter.

Thomas, R.F. (2001) Virgil and the Augustan Reception. Cambridge, Cambridge University Press.

Thon, C. (1828) Il Palazzo de' Cesari sul Monte Palatino. Rome, Società Tipografica.

Tillyard, E.M.W. (1917) A Cybele altar in London. Journal of Roman Studies 7: 284-8.

Turcan, R. (1996) The Cults of the Roman Empire. Oxford, Blackwell.

Vermaseren, M.J. (1966) The Legend of Attis in Greek and Roman Art (Études preliminaires aux religions orientales dans l'empire romain 9). Leiden, Brill.

Vermaseren, M.J. (1977) Cybele and Attis: the Myth and the Cult. London, Thames and Hudson.

Vermaseren, M.J. (1977-89) Corpus Cultus Cybelae Attidisque (Études preliminaires aux religions orientales dans l'empire romain 50), 7 vols. Leiden, Brill.

Vermaseren, M.J. (1986) Attis. In Lexicon Iconographicum Mythologiae Classicae III.1: 22-44. Zurich/ Munich, Artemis.

Weinstock, S. (1957) The image of the chair of Germanicus. Journal of Roman Studies 47: 144-54.

Weinstock, S. (1971) Divus Julius. Oxford, Clarendon Press.

Wiseman, T.P. (1974) Cinna the Poet and other Roman Essays. Leicester, Leicester University Press.

Wiseman, T.P. (1982) Philodemus 26.3 G-P. Classical Quarterly 32: 475-6.

Wiseman, T.P. (1985) Catullus and His World - a Reappraisal. Cambridge, Cambridge University Press.

Wiseman, T.P. (1995) Remus: a Roman Myth. Cambridge, Cambridge University Press.

Wroth, W. (1894) Catalogue of the Greek Coins of Troas, Aeolis, and Lesbos. London, The Trustees of the British Museum.

Zanker, P. (1988) The Power of Images in the Age of Augustus. Ann Arbor, University of Michigan Press. 
